\title{
Enantioselective Total Synthesis of (+)-SCH 351448
}

\author{
Michael T. Crimmins and Grace S. Vanier \\ Department of Chemistry \\ University of North Carolina at Chapel Hill \\ Chapel Hill, NC 27599 \\ crimmins@email.unc.edu
}

\section{Experimental}

\section{A. Materials and Methods}

Infrared (IR) spectra were obtained using a JASCO P-460 plus FT/IR. Proton and carbon nuclear magnetic resonance $\left({ }^{1} \mathrm{H}\right.$ and ${ }^{13} \mathrm{C}$ NMR) spectra were recorded on the following instruments: Bruker model Advance $400\left({ }^{1} \mathrm{H}\right.$ at $400 \mathrm{MHz},{ }^{13} \mathrm{C}$ at $\left.100 \mathrm{MHz}\right)$, and Bruker model Avance $500\left({ }^{1} \mathrm{H}\right.$ at $500 \mathrm{MHz} ;{ }^{13} \mathrm{C}$ at $\left.125 \mathrm{MHz}\right)$. Optical rotations were determined using a Jasco P-1010 polarimeter. Flash chromatography was carried out using silica gel (32 - $63 \mu \mathrm{m})$ purchased from Sorbent Technologies. Diethyl ether, tetrahydrofuran (THF), and dichloromethane $\left(\mathrm{CH}_{2} \mathrm{Cl}_{2}\right)$ were dried by being passed through a column of neutral alumina under nitrogen immediately prior to use. Alkylamines, benzene, 
toluene, and trimethylsilyl chloride (TMSCl) were distilled over $\mathrm{CaH}_{2}$ immediately prior to use. Dimethyl sulfoxide (DMSO) was distilled under reduced pressure from calcium hydride and stored over $4 \AA$ molecular sieves. Anhydrous $N, N$-dimethylformamide (DMF) was purchased from Aldrich in $1 \mathrm{~L}$ Sure/Seal ${ }^{\mathrm{TM}}$ bottles. Anhydrous methanol was purchased from ACROS in $1 \mathrm{~L}$ AcroSeal $^{\mathrm{TM}}$ bottles. Titanium(IV) isopropoxide was distilled under reduced pressure and stored in a dark dessicator. Allyl iodide was distilled and stored over copper wire at $-20^{\circ} \mathrm{C}$. Pivaloyl chloride was distilled and stored over $4 \AA$ molecular sieves. All other commercially available reagents were used without further purification. All air and water sensitive reactions were performed in flasks flame dried under a positive flow of argon and conducted under an argon atmosphere. 


\section{B. Experimental Procedures}

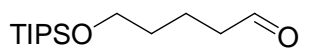

5-Tri-isopropylsilyloxypentanal. To a 1L three-neck flask equipped with a mechanical stirrer was added sodium hydride (60\% dispersion in mineral oil, $7.7 \mathrm{~g}, 192.5 \mathrm{mmol}$ ). The sodium hydride was washed three times with hexanes and dried under an atmosphere of argon. $200 \mathrm{~mL}$ of THF was then added and the resulting heterogeneous solution was cooled to $0{ }^{\circ} \mathrm{C}$. 1,5-pentanediol (20 mL, $\left.190.9 \mathrm{mmol}\right)$ in $100 \mathrm{~mL}$ of THF was added via cannula. The reaction was warmed to room temperature for 30 minutes, and then recooled to $0{ }^{\circ} \mathrm{C}$. Triisopropylsilylchloride (41 mL, $191.6 \mathrm{mmol}$ ) in $200 \mathrm{~mL}$ of THF was added via cannula, and the reaction was allowed to stir for 40 minutes at $0{ }^{\circ} \mathrm{C}$. The reaction was quenched by the addition of water and the mixture was extracted three times with diethyl ether. The combined organic layers were dried over $\mathrm{Na}_{2} \mathrm{SO}_{4}$ and concentrated in vacuo. Purification by flash column chromatography (15\% EtOAc/hexanes) afforded $37.7 \mathrm{~g}$ (76\%) of the silyl ether: ${ }^{1} \mathrm{H}$ NMR (400 MHz, $\left.\mathrm{CDCl}_{3}\right) \delta 3.67(\mathrm{t}, J=6.6 \mathrm{~Hz}, 2 \mathrm{H}), 3.63(\mathrm{q}, J=12.0,6.4 \mathrm{~Hz}, 2 \mathrm{H})$, 1.52-1.61 (m, 4H), 1.34-1.44 (m, 2H), 0.98-1.10 (m, 21H); ${ }^{13} \mathrm{C}$ NMR (100 MHz, $\left.\mathrm{CDCl}_{3}\right)$ $\delta$ 63.27, 62.97, 32.65, 32.52, 22.00, 18.00, 11.98; IR (film) 3348, 2941, 2866, 1462, 1384, 1106, 882, $680 \mathrm{~cm}^{-1}$; MS (electrospray ionization) calculated for $\mathrm{C}_{14} \mathrm{H}_{33} \mathrm{O}_{2} \mathrm{Si}[\mathrm{M}+\mathrm{H}]^{+}$: 261.2, found 261.3. A flame dried three-neck 2 L flask equipped with a mechanical stirrer, internal thermometer, and an addition funnel was charged with oxalyl chloride (2.0 $\mathrm{M}$ in dichloromethane, $75.0 \mathrm{~mL}, 150.0 \mathrm{mmol}$ ) in $300 \mathrm{~mL}$ of dichloromethane. After the solution was cooled to $-78{ }^{\circ} \mathrm{C}$, dimethyl sulfoxide $(23 \mathrm{~mL}, 324.1 \mathrm{mmol})$ in $320 \mathrm{~mL}$ of dichloromethane was added dropwise via an addition funnel at such a rate as to maintain the reaction temperature below $-65{ }^{\circ} \mathrm{C}$. After stirring at $-78{ }^{\circ} \mathrm{C}$ for 30 minutes, 5-tri- 
isopropylsilyloxy-1-pentanol (35.7g, $137.0 \mathrm{mmol})$ in $105 \mathrm{~mL}$ of dichloromethane was added dropwise via an addition funnel at such a rate as to maintain the reaction temperature below $-65^{\circ} \mathrm{C}$. After stirring for an additional 20 minutes at $-78^{\circ} \mathrm{C}$, triethylamine $(95 \mathrm{~mL}, 681.6$ mmol) was added dropwise maintaining a temperature below $-65{ }^{\circ} \mathrm{C}$. The reaction was allowed to stir five minutes at $\quad-78^{\circ} \mathrm{C}$ and then warmed to room temperature upon removal of the cold bath. The reaction was quenched with water and the mixture was extracted twice with ethyl acetate. The combined organic layers were dried over $\mathrm{Na}_{2} \mathrm{SO}_{4}$ and concentrated in vacuo. The crude aldehyde was filtered through a small plug of silica gel eluting with dichloromethane. The aldehyde was used immediately in the following Grignard reaction: ${ }^{1} \mathrm{H}$ NMR (400 MHz, $\left.\mathrm{CDCl}_{3}\right) \delta 9.74(\mathrm{t}, J=1.8 \mathrm{~Hz}, 1 \mathrm{H}), 3.68(\mathrm{t}, J=1.8 \mathrm{~Hz}, 2 \mathrm{H}), 2.44(\mathrm{dt}, J=$ 7.2, $2.0 \mathrm{~Hz}, 2 \mathrm{H}), 1.29-1.37$ (m, 2H), 1.12-1.20 (m, 2H), 0.54-0.68 (m, 21H).

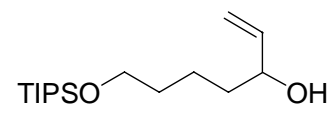

Allylic alcohol 17. A three-neck $2 \mathrm{~L}$ flask equipped with a mechanical stirrer, addition funnel, and condenser was charged with magnesium shavings (10.0 g, $411 \mathrm{mmol})$ in $60 \mathrm{~mL}$ of THF. $10 \mathrm{~mL}$ of a $160 \mathrm{~mL}$ solution of vinyl bromide (34.0 mL, $482 \mathrm{mmol})$ in THF was added and the reaction was gently heated until initiation was achieved. An additional 250 $\mathrm{mL}$ of THF was added to the reaction and the remaining vinyl bromide solution was added dropwise via addition funnel at a rate to maintain a gentle reflux. The reaction was stirred 30 minutes at room temperature and then cooled to $0{ }^{\circ} \mathrm{C}$. 5-Tri-isopropylsilyloxypentanal (137 mmol) in $140 \mathrm{~mL}$ of THF was added dropwise via addition funnel. After stirring for five minutes at $0{ }^{\circ} \mathrm{C}$, the reaction was carefully quenched with saturated aqueous $\mathrm{NH}_{4} \mathrm{Cl}$. The organic layer was washed with water and $10 \% \mathrm{HCl}$. The aqueous layers were back extracted twice with hexanes and the combined organic layers were dried over $\mathrm{Na}_{2} \mathrm{SO}_{4}$ 
followed by concentration in vacuo. Purification by flash column chromatography (10\% to 17.5\% EtOAc/hexanes) afforded $37.2 \mathrm{~g}$ (95\% over two steps) of racemic allylic alcohol 17: ${ }^{1} \mathrm{H}$ NMR (400 MHz, $\mathrm{CDCl}_{3}$ ) $\delta 5.34$ (ddd, $\left.J=20.8,10.4,6.4 \mathrm{~Hz}, 1 \mathrm{H}\right), 5.20(\mathrm{dt}, J=17.2,1.2$ Hz, 1H), 5.08 (dt, $J=10.4,1.2 \mathrm{~Hz}, 1 \mathrm{H}$ ), 4.09 (dt, $J=11.6,6.0 \mathrm{~Hz}, 1 \mathrm{H}), 3.67$ (t, $J=6.4 \mathrm{~Hz}$, 2H), $1.48-1.59$ (m, 4H), 1.35-1.47 (m, 2H), 0.99-1.11 (m, 21H); ${ }^{13} \mathrm{C}$ NMR (100 MHz, $\left.\mathrm{CDCl}_{3}\right) \delta 141.21,114.60,63.27,36.77,32.80,21.66,18.02,12.00 ; \quad$ IR (film) 3351, 2942, 2866, 1463, 1108, 993, 920, 882, $680 \mathrm{~cm}^{-1}$; MS (electrospray ionization) calculated for $\mathrm{C}_{16} \mathrm{H}_{34} \mathrm{O}_{2} \mathrm{SiNa}[\mathrm{M}+\mathrm{Na}]^{+}:$309.22, found 309.20.

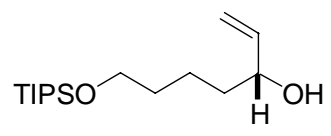

R-Allylic alcohol 17. A $500 \mathrm{~mL}$ flask was charged with $4 \AA$ molecular sieves (2.4 g, 25\% by weight), alcohol 17 (9.6g, $33.5 \mathrm{mmol})$, and (+)-dicyclohexyl tartrate (1.6g, $5.1 \mathrm{mmol})$ in $135 \mathrm{~mL}$ of dichloromethane. After cooling the reaction to $-20^{\circ} \mathrm{C}$, titanium(IV) isopropoxide (1.1 mL, $3.6 \mathrm{mmol})$ was added dropwise via syringe. The reaction was stirred for 30 minutes at $-20{ }^{\circ} \mathrm{C}$ followed by addition of tert-butyl hydroperoxide (5.7 $\mathrm{M}$ in dichloromethane, $4.1 \mathrm{~mL}, 23.4 \mathrm{mmol})$. After stirring for 2 days at $-20^{\circ} \mathrm{C}$, the reaction was warmed to $0{ }^{\circ} \mathrm{C}$ and quenched with an aqueous solution of citric acid and ferric sulfate. The mixture was stirred one hour at room temperature followed by extraction of the aqueous layer three times with dichloromethane. The combined organic layers were dried over $\mathrm{Na}_{2} \mathrm{SO}_{4}$ followed by concentration in vacuo. Purification by flash column chromatography (10\% EtOAc/hexanes) afforded $4.22 \mathrm{~g}(44 \%)$ of $17:{ }^{1} \mathrm{H}$ NMR (400 MHz, $\left.\mathrm{CDCl}_{3}\right) \delta 5.85$ (ddd, $J=16.8,10.4,6.4 \mathrm{~Hz}, 1 \mathrm{H}$ ), 5.20 (dt, $J=17.2,1.4 \mathrm{~Hz}, 1 \mathrm{H}$ ), 5.08 (dt, $J=10.4,1.4 \mathrm{~Hz}$, 
1H), $3.66(\mathrm{t}, J=6.6,2 \mathrm{H}), 1.48-1.59(\mathrm{~m}, 4 \mathrm{H}), 1.36-1.47(\mathrm{~m}, 2 \mathrm{H}), 0.98-1.11(\mathrm{~m}, 21 \mathrm{H}) ;{ }^{13} \mathrm{C}$ NMR (100 MHz, $\left.\mathrm{CDCl}_{3}\right) \delta$ 141.62, 115.01, 73.65, 63.68, 37.17, 33.20, 22.07, 18.43, 12.40;

IR (film) 3358, 2942, 2866, 1463, 1384, 1108, 993, 920, 882, 765, $680 \mathrm{~cm}^{-1} ;[\alpha]^{25}=-3.97$ $\left(c=0.955, \mathrm{CH}_{2} \mathrm{Cl}_{2}\right) ;$ MS (electrospray ionization) calculated for $\mathrm{C}_{16} \mathrm{H}_{34} \mathrm{O}_{2} \mathrm{SiNa}[\mathrm{M}+\mathrm{Na}]^{+}$: 309.22, found 309.20.

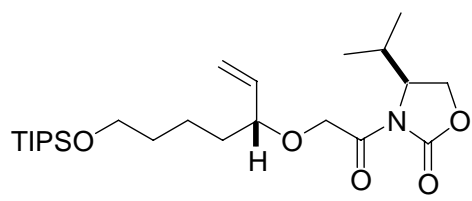

$N$-acyloxazolidinone 19. To a $250 \mathrm{~mL}$ flask equipped with an addition funnel was added sodium hydride (60\% dispersion in mineral oil, $7.0 \mathrm{~g}, 175 \mathrm{mmol}$ ). The sodium hydride was washed three times with hexanes and dried under an atmosphere of argon. $30 \mathrm{~mL}$ of THF was added and the resultant heterogeneous solution was cooled to $0{ }^{\circ} \mathrm{C}$. Bromoacetic acid ( $8.9 \mathrm{~g}, 64.1 \mathrm{mmol}$ ) in $28 \mathrm{~mL}$ of THF was added via addition funnel. Following stirring at 0 ${ }^{\circ} \mathrm{C}$ for 30 minutes, alcohol 17 (16.7 g, $\left.58.3 \mathrm{mmol}\right)$ in $58 \mathrm{~mL}$ of $N, N$-dimethylformamide was added dropwise via addition funnel. After stirring for an additional 30 minutes at $0{ }^{\circ} \mathrm{C}$, the reaction was warmed to room temperature and stirred overnight. The heterogeneous solution was cooled to $0{ }^{\circ} \mathrm{C}$ and quenched slowly by the addition of water. The mixture was acidified to $\mathrm{pH} 2$ with 10\% hydrochloric acid followed by extraction of the aqueous layer three times with ethyl acetate. The combined organic layers were washed with brine and dried over $\mathrm{Na}_{2} \mathrm{SO}_{4}$ followed by concentration in vacuo. Purification by flash column chromatography (10\% to 35\% EtOAc/hexanes) afforded $19.3 \mathrm{~g}$ (96\%) of the glycolic acid: ${ }^{1} \mathrm{H}$ NMR (400 MHz, $\left.\mathrm{CDCl}_{3}\right) \delta 10.42$ (bs, $1 \mathrm{H}$ ), 5.62 (ddd, $J=18.4,10.4,8.0 \mathrm{~Hz}, 1 \mathrm{H}$ ), 5.16$5.23(\mathrm{~m}, 2 \mathrm{H}), 4.05$ (dd, $J=44.8,16.8 \mathrm{~Hz}, 2 \mathrm{H}), 3.73(\mathrm{q}, J=14.6,6.6 \mathrm{~Hz}, 1 \mathrm{H}), 3.64(\mathrm{t}, J=$ 6.6 Hz, 2H), 1.65-1.73 (m, 1H), 1.47-1.56 (m, 3H), 1.34-1.45 (m, 2H), 0.97-1.09 (m, 21H); 
${ }^{13} \mathrm{C}$ NMR $\left(100 \mathrm{MHz}, \mathrm{CDCl}_{3}\right) \delta 175.47,137.43,118.72,82.56,64.91,63.18,34.82,32.70$, 21.48, 17.96, 11.93; IR (film) 2943, 2866, 1732, 1463, 1384, 1246, 1109, 995, 929, 882, $764,681 \mathrm{~cm}^{-1} ;[\alpha]_{\mathrm{D}}^{26}=+15.7\left(c=0.38, \mathrm{CH}_{2} \mathrm{Cl}_{2}\right)$; MS (electrospray ionization) calculated for $\mathrm{C}_{18} \mathrm{H}_{36} \mathrm{O}_{4} \mathrm{SiNa}[\mathrm{M}+\mathrm{Na}]^{+}$: 367.23, found 367.30.

Into a $1 \mathrm{~L}$ flask was added the glycolic acid from above (14.8 g, $43.0 \mathrm{mmol}), 215$ $\mathrm{mL}$ diethyl ether, and triethylamine $(9.0 \mathrm{~mL}, 64.6 \mathrm{mmol})$. The solution was cooled to -78 ${ }^{\circ} \mathrm{C}$, and pivaloyl chloride $(7.9 \mathrm{~mL}, 64.1 \mathrm{mmol})$ was added dropwise. After stirring ten minutes at $-78{ }^{\circ} \mathrm{C}$, the reaction was warmed to $0{ }^{\circ} \mathrm{C}$ for 1 hour followed by recooling to -78 ${ }^{\circ} \mathrm{C}$.

Into a $250 \mathrm{~mL}$ flask fitted with an addition funnel was added (S)-4-isopropyloxazolidin-2-one (8.9g, $68.9 \mathrm{mmol})$ in $180 \mathrm{ml}$ of THF. After cooling to $-78{ }^{\circ} \mathrm{C}, n$ butyllithium (1.6 M solution in hexanes, $40 \mathrm{~mL}, 64.0 \mathrm{mmol}$ ) was added dropwise via addition funnel. The reaction was allowed to stir for 15 minutes at $-78^{\circ} \mathrm{C}$. The lithiated oxazolidinone was transferred by cannula into the mixed anhydride followed by warming to $0{ }^{\circ} \mathrm{C}$ for 30 minutes. The reaction was quenched with saturated $\mathrm{NH}_{4} \mathrm{Cl}$. The solution was extracted twice with ethyl acetate, and the combined organic extracts were dried over $\mathrm{Na}_{2} \mathrm{SO}_{4}$ and concentrated in vacuo. Purification by flash chromatography ( $10 \%$ to $35 \%$ EtOAc/hexanes) afforded $15.9 \mathrm{~g}(81 \%)$ of $19:{ }^{1} \mathrm{H}$ NMR (400 MHz, $\left.\mathrm{CDCl}_{3}\right) \delta 6.64$ (ddt, $J=$ 18.8, 10.8, 8.4 Hz, 1H), 5.14-5.18 (m, 2H), 4.59 (q, $J=40.0,18.0 \mathrm{~Hz}, 2 \mathrm{H}), 4.38-4.41$ (m, 1H), 4.29 (t, $J=8.6 \mathrm{~Hz}, 1 \mathrm{H}), 4.21(\mathrm{dd}, J=9.2,3.2 \mathrm{~Hz}, 1 \mathrm{H}), 3.73$ (q, $J=14.4,6.8 \mathrm{~Hz}, 1 \mathrm{H}$ ), $3.63(\mathrm{t}, J=6.6 \mathrm{~Hz}, 2 \mathrm{H}), 2.35-2.43$ (m, 1H), 1.69-1.77 (m, 1H), 1.47-1.57 (m, 3H), 1.36-1.46 (m, 2H), 0.99-1.10 (m, 21H), 0.85 (dd, $J=20.8,7.2 \mathrm{~Hz}, 6 \mathrm{H}) ;{ }^{13} \mathrm{C}$ NMR (100 MHz, $\left.\mathrm{CDCl}_{3}\right)$ $\delta 170.54,153.94,138.04,118.19,82.47,67.72,64.22,63.26,58.13,34.96,32.84,28.07$, 
21.50, 17.97, 14.49, 11.93; IR (film) 2942, 2866, 1785, 1719, 1464, 1390, 1302, 1258, 1209, 1106, 994, 882, 773, 717, $680 \mathrm{~cm}^{-1} ;[\alpha]^{26}=+50.7\left(c=0.31, \mathrm{CH}_{2} \mathrm{Cl}_{2}\right) ; \quad$ MS (electrospray ionization) calculated for $\mathrm{C}_{24} \mathrm{H}_{45} \mathrm{NO}_{5} \mathrm{SiNa}[\mathrm{M}+\mathrm{Na}]^{+}:$478.30, found 478.30 .

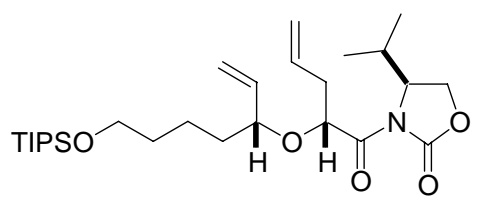

A three-neck $250 \mathrm{~mL}$ flask equipped with an addition funnel and a low temperature thermometer was charged with $\mathrm{NaN}\left(\mathrm{SiMe}_{3}\right)_{2}(0.75 \mathrm{M}, 28 \mathrm{~mL}, 21.0 \mathrm{mmol})$ in $60 \mathrm{~mL}$ of THF. Upon cooling the solution to $-78{ }^{\circ} \mathrm{C}$, glycolate 19 (4.78 g, $\left.10.5 \mathrm{mmol}\right)$ in $40 \mathrm{~mL}$ of THF was added dropwise via addition funnel at such a rate to maintain the reaction temperature below $-65{ }^{\circ} \mathrm{C}$. After stirring at $-78{ }^{\circ} \mathrm{C}$ for 1 hour, allyl iodide $(4.8 \mathrm{~mL}, 52.5 \mathrm{mmol})$ was added dropwise via syringe. After stirring 15 minutes at $-78^{\circ} \mathrm{C}$, the reaction was slowly warmed to $-45^{\circ} \mathrm{C}$ and held at that temperature for 1.5 hours. The reaction was quenched slowly with saturated $\mathrm{NH}_{4} \mathrm{Cl}$ and warmed to room temperature. The reaction was extracted three times with ethyl acetate. The combined organic layers were dried over $\mathrm{Na}_{2} \mathrm{SO}_{4}$ and concentrated in vacuo. Purification by flash column chromatography (5\% to $10 \%$ EtOAc/hexanes) afforded $3.64 \mathrm{~g}(70 \%)$ of the alkylation product: ${ }^{1} \mathrm{H}$ NMR $\left(400 \mathrm{MHz}, \mathrm{CDCl}_{3}\right) \delta 5.86$ (ddt, $J$ $=17.2,10.0,7.2 \mathrm{~Hz}, 1 \mathrm{H}), 5.60(\mathrm{ddd}, J=17.2,10.0,8.0 \mathrm{~Hz}, 1 \mathrm{H}), 5.15-5.19(\mathrm{~m}, 2 \mathrm{H}), 5.10$ (d, $J=1.6 \mathrm{~Hz}, 1 \mathrm{H}), 5.02-5.06(\mathrm{~m}, 3 \mathrm{H}), 4.48(\mathrm{dt}, J=8.4,3.4 \mathrm{~Hz}, 1 \mathrm{H}), 4.30(\mathrm{t}, J=8.8 \mathrm{~Hz}, 1 \mathrm{H})$, 4.20 (dd, $J=8.8,3.2 \mathrm{~Hz}, 1 \mathrm{H}), 3.64$ (t, $J=6.8 \mathrm{~Hz}, 2 \mathrm{H}), 5.56$ (q, $J=14.4,6.4 \mathrm{~Hz}, 1 \mathrm{H}), 2.51-$ 2.58 (m, 1H), 2.39-2.46 (m, 1H), 2.28 (ddq, $J=14.0,11.2,7.2,4.0 \mathrm{~Hz}, 1 \mathrm{H}), 1.64-1.73(\mathrm{~m}$, 1H), 1.44-1.56 (m, 3H), 1.33-1.44 (m, 2H), 0.97-1.09 (m, 21H), 0.86 (dd, $J=17.8,7.0 \mathrm{~Hz}$, 6H); ${ }^{13} \mathrm{C}$ NMR (100 MHz, $\left.\mathrm{CDCl}_{3}\right) \delta 172.81,153.51,138.42,133.40,117.97,117.65,80.71$, 74.15, 63.89, 63.36, 58.16, 37.77, 35.27, 32.95, 28.32, 21.36, 18.00, 14.75, 11.97; IR (film) 
2942, 2866, 1784, 1714, 1464, 1388, 1301, 1246, 1204, 1103, 994, 922, 882, 773, $681 \mathrm{~cm}^{-1}$; $[\alpha]_{D}^{26}=+53.3\left(c=0.26, \mathrm{CH}_{2} \mathrm{Cl}_{2}\right) ; \quad$ MS (electrospray ionization) calculated for $\mathrm{C}_{27} \mathrm{H}_{49} \mathrm{NO}_{5} \mathrm{SiNa}[\mathrm{M}+\mathrm{Na}]^{+}:$518.33, found 518.40 .

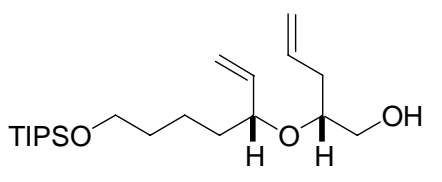

To a $500 \mathrm{~mL}$ flask was added the alkylation product from above $(3.5 \mathrm{~g}, 7.1 \mathrm{mmol})$, anhydrous methanol $(0.430 \mathrm{~mL}, 10.6 \mathrm{mmol})$, and $100 \mathrm{~mL}$ of diethyl ether. The reaction was cooled to $0{ }^{\circ} \mathrm{C}$ followed by addition of lithium borohydride (2.0 M in THF, $5.3 \mathrm{~mL}, 10.6$ mmol) dropwise via syringe. After stirring at $0{ }^{\circ} \mathrm{C}$ for 1 hour, the reaction was slowly quenched by the addition of a saturated aqueous potassium/sodium tartrate solution. The mixture was warmed to room temperature and stirred vigorously overnight. The aqueous layer was extracted three times with ethyl acetate. The combined organic layers were dried over $\mathrm{Na}_{2} \mathrm{SO}_{4}$ and concentrated in vacuo. Purification by flash column chromatography (17.5\% EtOAc/hexanes) afforded $2.25 \mathrm{~g}(86 \%)$ of diene 20: ${ }^{1} \mathrm{H}$ NMR (400 MHz, $\left.\mathrm{CDCl}_{3}\right)$ $\delta$ 5.63-5.79 (m, 2H), 5.10-5.16 (m, 2H), 4.98-5.06 (m, 2H), 3.77 (q, $J=13.6,6.8 \mathrm{~Hz}, 1 \mathrm{H})$, 3.64 (app t, $J=6.4 \mathrm{~Hz}, 3 \mathrm{H}$ ), 3.44-3.50 (m, 2H), 2.18-2.32 (m, 2H), 1.93 (bs, 1H), 1.56-1.66 (m, 1H), 1.48-1.54 (m, 2H), 1.34-1.47 (m, 3H), 0.92-1.10 (m, 21H); ${ }^{13} \mathrm{C}$ NMR (100 MHz, $\left.\mathrm{CDCl}_{3}\right) \delta 139.64,134.51,117.06,116.53,80.53,76.74,63.47,63.17,36.51,35.37,32.76$, 21.73, 17.98, 11.95; IR (film) 3444, 3077, 2942, 2866, 1642, 1463, 1384, 1247, 1103, 994, 920, 882, 763, 721, 681, $658 \mathrm{~cm}^{-1} ;[\alpha]^{26}{ }_{\mathrm{D}}=+0.49\left(c=0.45, \mathrm{CH}_{2} \mathrm{Cl}_{2}\right) ;$ MS (electrospray ionization) calculated for $\mathrm{C}_{21} \mathrm{H}_{42} \mathrm{O}_{3} \mathrm{SiNa}[\mathrm{M}+\mathrm{Na}]^{+}$: 393.28, found 393.40.

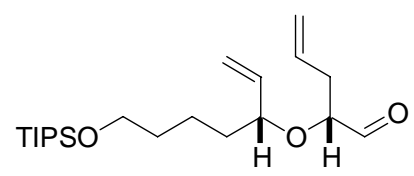


A three-neck $100 \mathrm{~mL}$ flask equipped with a mechanical stirrer, low temperature thermometer, and an addition funnel was charged with oxalyl chloride (2.0 M in dichloromethane, $3.3 \mathrm{~mL}, 6.6 \mathrm{mmol}$ ) in $13 \mathrm{~mL}$ of dichloromethane. After the solution was cooled to $-78{ }^{\circ} \mathrm{C}$, dimethyl sulfoxide $(1.0 \mathrm{~mL}, 14.1 \mathrm{mmol})$ in $14 \mathrm{~mL}$ of dichloromethane was added dropwise via an addition funnel at such a rate as to maintain the reaction temperature below $-65{ }^{\circ} \mathrm{C}$. After stirring at $-78{ }^{\circ} \mathrm{C}$ for 30 minutes, alcohol 20 (2.23 g, $\left.6.02 \mathrm{mmol}\right)$ in 4 $\mathrm{mL}$ of dichloromethane was added dropwise via an addition funnel at such a rate as to maintain the reaction temperature below $-65^{\circ} \mathrm{C}$. After stirring for an additional 20 minutes at $-78{ }^{\circ} \mathrm{C}$, triethylamine $(4.2 \mathrm{~mL}, 30.1 \mathrm{mmol})$ was added dropwise maintaining a temperature below $-65{ }^{\circ} \mathrm{C}$. The reaction was allowed to stir five minutes at $-78{ }^{\circ} \mathrm{C}$ and then warmed to room temperature upon removal of the cold bath. The reaction was quenched with water and the mixture was extracted twice with ethyl acetate. The combined organic layers were dried over $\mathrm{Na}_{2} \mathrm{SO}_{4}$ and concentrated in vacuo. The crude aldehyde was filtered through a small plug of silica gel eluting with dichloromethane. The aldehyde was used immediately in the following Wittig reaction: ${ }^{1} \mathrm{H}$ NMR $\left(400 \mathrm{MHz}, \mathrm{CDCl}_{3}\right) \delta 9.62(\mathrm{~d}, J=2.4 \mathrm{~Hz}, 1 \mathrm{H})$, 5.76 (ddt, $J=17.2,10.4,7.2 \mathrm{~Hz}, 1 \mathrm{H}$ ), 5.59 (ddd, $J=17.2,10.4,8.0 \mathrm{~Hz}, 1 \mathrm{H}$ ), 5.05-5.19 (m, 4H), 3.80 (ddd, $J=7.2,6.0,2.4 \mathrm{~Hz}, 1 \mathrm{H}$ ), 3.71 (q, $J=13.2,6.8 \mathrm{~Hz}, 1 \mathrm{H}$ ), 3.66 (t, $J=6.4 \mathrm{~Hz}$, 2H), 2.33-2.41 (m, 2H), 1.66-1.72 (m, 1H), 1.46-1.58 (m, 3H), 1.36-1.45 (m, 2H), 0.98-1.10 (m, 21H).

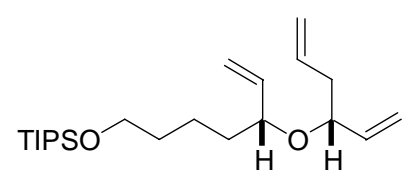

Triene 21. A $500 \mathrm{~mL}$ flask equipped with an addition funnel was charged with methyltriphenylphosphonium bromide $(8.6 \mathrm{~g}, 24.1 \mathrm{mmol})$ and $100 \mathrm{~mL}$ of toluene. 
Potassium tert-butoxide (2.0 g, $17.8 \mathrm{mmol})$ in $17 \mathrm{~mL}$ of THF was added dropwise via addition funnel. The resulting yellow slurry was stirred 1 hour at room temperature. The aldehyde from the previous experiment $(6.0 \mathrm{mmol})$ in $100 \mathrm{~mL}$ of toluene was added dropwise via addition funnel. The reaction was quenched immediately upon complete addition of the aldehyde with water. The mixture was extracted twice with hexanes. The combined organic layers were dried over $\mathrm{Na}_{2} \mathrm{SO}_{4}$ and concentrated in vacuo. Purification by flash column chromatography (2\% to 5\% EtOAc/hexanes) afforded $1.83 \mathrm{~g}$ (83\% over two steps) of triene 21: ${ }^{1} \mathrm{H}$ NMR $\left(400 \mathrm{MHz}, \mathrm{CDCl}_{3}\right) \delta 5.76(\mathrm{ddt}, J=17.2,10.0,6.8 \mathrm{~Hz}, 1 \mathrm{H})$, 5.56-5.65 (m, 2H), 5.10-5.16 (m, 3H), 4.97-5.08 (m, 3H), 3.77 (q, $J=14.4,6.8 \mathrm{~Hz}, 1 \mathrm{H})$, $3.71(\mathrm{q}, J=13.2,7.2 \mathrm{~Hz}, 1 \mathrm{H}), 3.64(\mathrm{t}, J=6.6 \mathrm{~Hz}, 2 \mathrm{H}), 2.17-2.35(\mathrm{~m}, 2 \mathrm{H}), 1.47-1.60(\mathrm{~m}$, 3H), $1.30-1.46(\mathrm{~m}, 3 \mathrm{H}), 0.99-1.11(\mathrm{~m}, 21 \mathrm{H}) ;{ }^{13} \mathrm{C} \mathrm{NMR}\left(100 \mathrm{MHz}, \mathrm{CDCl}_{3}\right) \delta$ 139.45, 138.94, 134.85, 116.92, 116.59, 116.52, 77.70, 77.25, 63.36, 40.33, 35.46, 32.88, 21.73, 18.02, 12.00; IR (film) 2942, 2866, 1463, 1106, 992, 922, $882 \mathrm{~cm}^{-1} ;[\alpha]^{27}=+13.2(c=$ 0.51, $\mathrm{CH}_{2} \mathrm{Cl}_{2}$ ); $\quad \mathrm{MS}$ (electrospray ionization) calculated for $\mathrm{C}_{22} \mathrm{H}_{42} \mathrm{O}_{2} \mathrm{SiNa}[\mathrm{M}+\mathrm{Na}]^{+}$: 389.29, found 389.30.

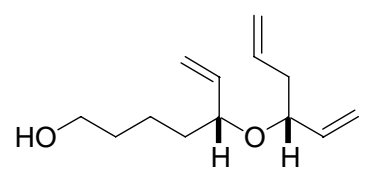

A $250 \mathrm{~mL}$ flask was charged with silyl ether 21 (6.1 g, $16.6 \mathrm{mmol})$ and 85 $\mathrm{mL}$ of THF. Tetrabutylammonium fluoride (1.0 M in THF, $34 \mathrm{~mL}, 34 \mathrm{mmol}$ ) was added dropwise via addition funnel. After stirring for 1 hour, the reaction was quenched with saturated $\mathrm{NH}_{4} \mathrm{Cl}$, and the aqueous layer was extracted three times with ethyl acetate. The combined organic layers were dried over $\mathrm{Na}_{2} \mathrm{SO}_{4}$ and concentrated in vacuo. Purification by flash column chromatography (5\% to $25 \%$ EtOAc/hexanes) afforded $3.31 \mathrm{~g}$ (95\%) of the 
primary alcohol: ${ }^{1} \mathrm{H}$ NMR $\left(400 \mathrm{MHz}, \mathrm{CDCl}_{3}\right) \delta 5.75$ (ddt, $\left.J=17.2,10.4,7.2 \mathrm{~Hz}, 1 \mathrm{H}\right), 5.56-$ 5.65 (m, 2H), 5.11-5.17 (m, 3H), 4.98-5.08 (m, 3H), 3.77 (q, $J=14.4,6.8 \mathrm{~Hz}, 1 \mathrm{H}), 3.72(\mathrm{q}$, $J=13.6,7.6 \mathrm{~Hz}, 1 \mathrm{H}), 3.61$ (q, $J=11.6,6.0 \mathrm{~Hz}, 2 \mathrm{H}), 2.17-2.53(\mathrm{~m}, 2 \mathrm{H}), 1.49-1.62(\mathrm{~m}, 2 \mathrm{H})$, 1.30-1.49 (m, 4H); ${ }^{13} \mathrm{C}$ NMR (100 MHz, $\left.\mathrm{CDCl}_{3}\right) \delta 139.27,138.82,134.76,117.08,116.81$, 116.61, 77.59, 77.28, 62.85, 40.29, 35.31, 32.62, 21.54; IR (film) 3366, 3077, 2937, 1642, 1422, 1059, 992, $922 \mathrm{~cm}^{-1} ;[\alpha]_{\mathrm{D}}^{25}=+32.0\left(c=0.53, \mathrm{CH}_{2} \mathrm{Cl}_{2}\right) ; \mathrm{MS}$ (electrospray ionization) calculated for $\mathrm{C}_{13} \mathrm{H}_{22} \mathrm{O}_{2} \mathrm{Na}[\mathrm{M}+\mathrm{Na}]^{+}$: 233.15, found 233.20.

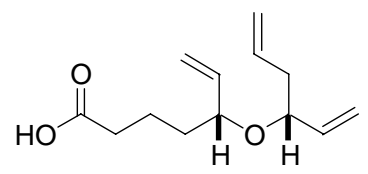

To a $250 \mathrm{~mL}$ flask was added the primary alcohol from above (3.14 g, 14.9 mmol) in $150 \mathrm{~mL}$ of acetone, and the flask was placed in a $15{ }^{\circ} \mathrm{C}$ water bath. Jones reagent (5.0 M in water, $9 \mathrm{~mL}, 45.0 \mathrm{mmol}$ ) was added dropwise until the solution remained orange. The mixture was stirred 45 minutes at $15{ }^{\circ} \mathrm{C}$, and then quenched by addition of isopropanol until the green color persisted. The reaction was diluted with ethyl acetate, and water was added to take up the salts formed in the quench. The aqueous layer was extracted three times with ethyl acetate. The combined organic layers were dried over $\mathrm{Na}_{2} \mathrm{SO}_{4}$ and concentrated in vacuo. Purification by flash column chromatography (5\% to $50 \%$ EtOAc/hexanes to $1 \% \mathrm{MeOH} / \mathrm{CH}_{2} \mathrm{Cl}_{2}$ ) afforded $2.91 \mathrm{~g}$ (87\%) of the acid: ${ }^{1} \mathrm{H}$ NMR (400 $\left.\mathrm{MHz}, \mathrm{CDCl}_{3}\right) \delta 5.75$ (ddt, $\left.J=17.2,10.4,7.2 \mathrm{~Hz}, 1 \mathrm{H}\right), 5.56-5.65(\mathrm{~m}, 2 \mathrm{H}), 5.11-5.18(\mathrm{~m}, 3 \mathrm{H})$, 4.98-5.09 (m, 3H), 3.75 (dq, $J=14.4,6.8,6.8 \mathrm{~Hz}, 2 \mathrm{H}), 2.32$ (q, $J=14.8,7.2 \mathrm{~Hz}, 2 \mathrm{H}), 2.17-$ 2.35 (m, 2H), 1.53-1.72 (m, 3H), 1.43-1.51 (m, 1H); $\left.{ }^{13} \mathrm{C} \mathrm{NMR} \mathrm{(100} \mathrm{MHz,} \mathrm{CDCl}_{3}\right) \delta$ 179.71, 138.88, 138.66, 134.67, 117.29, 117.06, 116.65, 77.35, 77.08, 40.24, 34.83, 33.86, 20.63; IR (film) 3078, 2936, 1712, 1643, 1423, 1315, 1071, 992, $924 \mathrm{~cm}^{-1} ;[\alpha]_{\mathrm{D}}^{24}=+37.4(c=$ 
0.17, $\mathrm{CH}_{2} \mathrm{Cl}_{2}$ ); $\mathrm{MS}$ (electrospray ionization) calculated for $\mathrm{C}_{13} \mathrm{H}_{20} \mathrm{O}_{3} \mathrm{Na}[\mathrm{M}+\mathrm{Na}]^{+}$: 247.13, found 247.10.

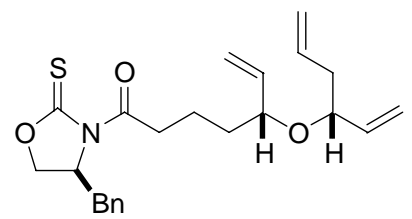

Acyl oxazolidinethione 7. A $100 \mathrm{~mL}$ flask was charged with the acid from above $(2.7 \mathrm{~g}$, $12.0 \mathrm{mmol})$ and $40 \mathrm{~mL}$ of dichloromethane. Dimethylformamide $(0.047 \mathrm{~mL}, 0.607 \mathrm{mmol})$ was added followed by dropwise addition of oxalyl chloride (2.0 M in dichloromethane, 8.4 $\mathrm{mL}, 16.8 \mathrm{mmol})$. After stirring for 1 hour the reaction was concentrated in vacuo. The acid chloride was used immediately in the following acylation reaction: ${ }^{1} \mathrm{H}$ NMR $(400 \mathrm{MHz}$, $\left.\mathrm{CDCl}_{3}\right) \delta 5.75(\mathrm{ddt}, J=17.2,10.4,6.8 \mathrm{~Hz}, 1 \mathrm{H}), 5.55-5.64(\mathrm{~m}, 2 \mathrm{H}), 5.14-5.20(\mathrm{~m}, 3 \mathrm{H}), 4.99-$ 5.12 (m, 3H), 3.74 (app dq, $J=6.4,6.4,6.4 \mathrm{~Hz}, 2 \mathrm{H}), 2.89$ (t, $J=7.2 \mathrm{~Hz}, 2 \mathrm{H}), 2.17-2.35$ (m, 2H), 1.66-1.82 (m, 2H), 1.44-1.62 (m, 2H).

To a flame dried $250 \mathrm{~mL}$ flask was added (S)-benzyl-2-oxazolidinethione (2.6 g, 13.4 mmol) and $40 \mathrm{~mL}$ of THF. After cooling to $-78{ }^{\circ} \mathrm{C}$, $n$-butyllithium $(2.5 \mathrm{M}$ in hexanes, $5.0 \mathrm{~mL}, 12.5$ mmol) was added dropwise via addition funnel. The reaction was stirred 30 minutes at -78 ${ }^{\circ} \mathrm{C}$ followed by dropwise addition of the acid chloride from above $(12.0 \mathrm{mmol})$ in $24 \mathrm{~mL}$ of THF. After stirring for an additional 45 minutes the reaction was quenched with $10 \%$ $\mathrm{K}_{2} \mathrm{CO}_{3}$. The aqueous layer was extracted three times with dichloromethane, and the combined organic layers were dried over $\mathrm{Na}_{2} \mathrm{SO}_{4}$. Concentration in vacuo followed by purification by flash column chromatography (10\% EtOAc/hexanes) provided 3.93 g (82\% over two steps) of acyl oxazolidinethione 7: ${ }^{1} \mathrm{H}$ NMR (400 MHz, $\left.\mathrm{CDCl}_{3}\right) \delta$ 7.29-7.33 (m, 2H), 7.23-7.27 (m, 1H), 7.18-7.20 (m, 2H), 5.77 (ddt, $J=17.2,10.4,7.2$ Hz, 1H), 5.63 (app ddd, $J=17.2,10.4,8.0 \mathrm{~Hz}, 2 \mathrm{H}), 5.09-5.19(\mathrm{~m}, 4 \mathrm{H}), 4.98-5.06$ (m, 2H), 4.90 (ddt, $J=64.4$, 
17.6, 8.0, $1.4 \mathrm{~Hz}, 2 \mathrm{H}), 3.25$ (dd, $J=13.2,2.8 \mathrm{~Hz}, 1 \mathrm{H}), 2.74$ (dd, $J=13.2,10.0 \mathrm{~Hz}, 1 \mathrm{H}$ ),

2.18-2.36 (m, 2H), 1.71-1.80 (m, 2H), 1.50-1.70 (m, 2H); ${ }^{13} \mathrm{C}$ NMR (100 MHz, $\left.\mathrm{CDCl}_{3}\right)$ $\delta$ 185.28, 173.90, 138.98, 138.77, 135.24, 134.77, 129.36, 128.96, 127.35, 117.23, 116.97, 116.57, 77.29, 77.16, 70.20, 59.88, 40.25, 37.57, 37.36, 34.80, 20.34; IR (film) 3075, 2930, 1698, 1642, 1497, 1454, 1401, 1366, 1324, 1191, 1073, 992, 967, 923, 746, $702 \mathrm{~cm}^{-1}$; $[\alpha]_{\mathrm{D}}^{25}=+90.2\left(c=0.44, \mathrm{CH}_{2} \mathrm{Cl}_{2}\right) ; \quad$ MS (electrospray ionization) calculated for $\mathrm{C}_{23} \mathrm{H}_{29} \mathrm{NO}_{3} \mathrm{SNa}[\mathrm{M}+\mathrm{Na}]^{+}:$422.18, found 422.30 .

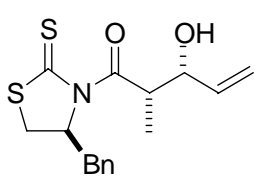

Acyl thiazolidinethione 8. A three-neck $2 \mathrm{~L}$ flask equipped with a mechanical stirrer and addition funnel was charged with propionate 7 (46.3 g, $174.4 \mathrm{mmol})$ in $1200 \mathrm{~mL}$ of dichloromethane, and the solution was cooled to $0{ }^{\circ} \mathrm{C}$. Titanium tetrachloride $(20.1 \mathrm{~mL}$, $183.3 \mathrm{mmol}$ ) was added dropwise, and the reaction was stirred for 20 minutes at $0{ }^{\circ} \mathrm{C}$. (-)Sparteine (41 mL, $178.4 \mathrm{mmol}$ ) in $20 \mathrm{~mL}$ of dichloromethane was then added dropwise to the reaction mixture producing a dark red solution. After stirring at $0{ }^{\circ} \mathrm{C}$ for 20 minutes, the reaction mixture was cooled to $-78{ }^{\circ} \mathrm{C}$ and $N$-methylpyrrolidinone (33.6 mL, $348.8 \mathrm{mmol}$ ) was added dropwise. The reaction was stirred 10 minutes at $-78{ }^{\circ} \mathrm{C}$, and then freshly distilled acrolein ( $24 \mathrm{~mL}, 355.8 \mathrm{mmol}$ ) was added dropwise. After stirring at $-78{ }^{\circ} \mathrm{C}$ for 2.5 hours the reaction was quenched with half-saturated $\mathrm{NH}_{4} \mathrm{Cl}$ and the mixture was warmed to room temperature. The aqueous layer was extracted twice with dichloromethane and the combined organic layers were dried over $\mathrm{Na}_{2} \mathrm{SO}_{4}$. Concentration in vacuo followed by purification by flash column chromatography (17.5\% to 35\% EtOAc/hexanes) provided 54.4 g (97\%) of acyl thiazolidinethione 8: ${ }^{1} \mathrm{H}$ NMR (400 MHz, $\left.\mathrm{CDCl}_{3}\right) \delta$ 7.27-7.31 (m, 2H), 
7.21-7.22 (m, 3H), 5.79 (ddd, $J=17.2,10.4,5.2 \mathrm{~Hz}, 1 \mathrm{H}$ ), 5.27 (dt, $J=17.2,1.6 \mathrm{~Hz}, 1 \mathrm{H}$ ), 5.22-5.27 (m, 1H), 5.15 (dt, $J=10.5,1.4 \mathrm{~Hz}, 1 \mathrm{H}), 4.52$ (dq, $J=13.6,6.8,4.0 \mathrm{~Hz}, 1 \mathrm{H}), 4.40-$ 4.44 (m, 1H), 3.34 (ddd, $J=11.4,7.2,0.8 \mathrm{~Hz}, 1 \mathrm{H}$ ), 3.18 (dd, $J=13.2,3.6 \mathrm{~Hz}, 1 \mathrm{H}$ ), 3.00 (dd, $J=13.0,10.6 \mathrm{~Hz}, 1 \mathrm{H}), 2.85$ (d, $J=11.6 \mathrm{~Hz}, 1 \mathrm{H}), 2.57$ (d, $J=3.6 \mathrm{~Hz}, 1 \mathrm{H}), 1.20$ (d, $J=6.8$ $\mathrm{Hz}, 3 \mathrm{H}) ;{ }^{13} \mathrm{C}$ NMR (100 MHz, $\left.\mathrm{CDCl}_{3}\right) \delta 201.36,177.38,137.59,136.35,129.41,128.88$, 127.23, 116.27, 73.54, 68.91, 43.80, 36.69, 32.23, 11.05; IR (film) 3446, 1695, 1454, 1342, $1261,1192,1166,1136,1030,744,702 \mathrm{~cm}^{-1} ;[\alpha]^{27}=+179.8\left(c=2.6, \mathrm{CH}_{2} \mathrm{Cl}_{2}\right) ; \mathrm{MS}$ (electrospray ionization) calculated for $\mathrm{C}_{16} \mathrm{H}_{19} \mathrm{NO}_{2} \mathrm{~S}_{2} \mathrm{Na}[\mathrm{M}+\mathrm{Na}]^{+}$: 344.08, found 344.10.

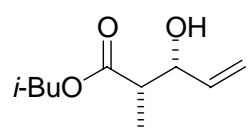

A 2 L flask was charged with acyl thiazolidinethione 8 (36 g, $112 \mathrm{mmol}$ ) and $230 \mathrm{~mL}$ of dichloromethane. Imidazole (11.5 g, $169 \mathrm{mmol})$ was added to the solution, and the reaction was stirred until complete solution of the imidazole. 2-Methyl-1propanol(103 $\mathrm{mL}, 1116 \mathrm{mmol})$ was then added and the resulting reaction mixture was stirred at room temperature overnight. The reaction was quenched by the addition of water, and the aqueous layer was then extracted twice with dichloromethane. The combine organic layers were concentrated in vacuo, and the resulting residue was diluted with hexanes and a minimal amount of ethyl acetate. The organic layer was washed twice with $1 \mathrm{M}$ sodium hydroxide and dried over $\mathrm{Na}_{2} \mathrm{SO}_{4}$. Concentration in vacuo and purification by flash column chromatography (10\% EtOAc/hexanes) provided $17.5 \mathrm{~g}$ (84\%) of the isobutyl ester: ${ }^{1} \mathrm{H}$ NMR (400 MHz, $\left.\mathrm{CDCl}_{3}\right) \delta 5.80$ (ddd, $\left.J=17.2,10.8,5.6 \mathrm{~Hz}, 1 \mathrm{H}\right), 5.28$ (dt, $J=17.2,1.6 \mathrm{~Hz}$, 1H), 5.16 (dt, $J=10.6,1.4 \mathrm{~Hz}, 1 \mathrm{H}), 4.35-4.40(\mathrm{~m}, 1 \mathrm{H}), 3.82-3.90$ (m, 2H), 2.73 (d, $J=5.2$ Hz, 1H), 2.61 (dq, $J=14.4,7.2,4.4 \mathrm{~Hz}, 1 \mathrm{H}), 1.91$ (dtd, $J=20.0,13.2,6.8 \mathrm{~Hz}, 1 \mathrm{H}), 1.15$ (d, 
$J=7.2 \mathrm{~Hz}, 3 \mathrm{H}), 0.91(\mathrm{~d}, J=6.8 \mathrm{~Hz}, 6 \mathrm{H}) ;{ }^{13} \mathrm{C} \mathrm{NMR}\left(100 \mathrm{MHz}, \mathrm{CDCl}_{3}\right) \delta 175.29,137.41$, 116.18, 73.04, 70.76, 44.67, 27.66, 19.02, 11.23; IR (film) 3472, 2965, 1732, 1470, 1381, 1347, 1251, 1191, 1034, 991, $926 \mathrm{~cm}^{-1} ; \quad[\alpha]_{\mathrm{D}}^{27}=+20.5\left(c=2.17, \mathrm{CH}_{2} \mathrm{Cl}_{2}\right) ; \quad \mathrm{MS}$ (electrospray ionization) calculated for $\mathrm{C}_{10} \mathrm{H}_{18} \mathrm{O}_{3} \mathrm{Na}[\mathrm{M}+\mathrm{Na}]^{+}$: 209.12, found 209.20.

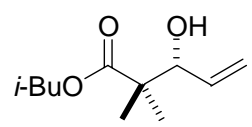

Gem-dimethyl isobutyl ester 9. A three-neck $1 \mathrm{~L}$ flask equipped with an addition funnel and a low temperature thermometer was charged with diisopropylamine (37 mL, $264 \mathrm{mmol}$ ) and $350 \mathrm{~mL}$ of THF. The solution was cooled to $-78^{\circ} \mathrm{C}$ followed by dropwise addition of $n$ butyllithium ( $88 \mathrm{~mL}, 220 \mathrm{mmol}$ ). After stirring 45 minutes at $-78{ }^{\circ} \mathrm{C}$, the isobutyl ester from above(16.4 g, $88.0 \mathrm{mmol})$ in $100 \mathrm{~mL}$ of THF was added dropwise. The reaction was warmed to $-20{ }^{\circ} \mathrm{C}$ and stirred for 30 minutes followed by recooling to $-78{ }^{\circ} \mathrm{C}$. Freshly distilled iodomethane (55 mL, $883 \mathrm{mmol}$ ) was added dropwise, and the reaction was stirred 30 minutes at $-78{ }^{\circ} \mathrm{C}$. The reaction mixture was then warmed to $-37^{\circ} \mathrm{C}$ and stirred for 2 days. The reaction was quenched by the addition of acetic acid in diethyl ether. The resulting solution was poured into a 1:1 diethyl ether:water solution. The aqueous layer was extracted three times with diethyl ether, and the combined organic layers were dried over $\mathrm{Na}_{2} \mathrm{SO}_{4}$. Concentration in vacuo and purification by flash column chromatography (10\% EtOAc/hexanes) provided $17.1 \mathrm{~g}$ (97\%) of the gem-dimethyl ester 9: ${ }^{1} \mathrm{H}$ NMR $(400 \mathrm{MHz}$, $\left.\mathrm{CDCl}_{3}\right) \delta 5.84(\mathrm{ddd}, J=16.8,10.4,6.4 \mathrm{~Hz}, 1 \mathrm{H}), 5.28(\mathrm{dt}, J=17.2,1.6 \mathrm{~Hz}, 1 \mathrm{H}), 5.20$ (dq, $J$ $=10.4,1.6,1.3 \mathrm{~Hz}, 1 \mathrm{H}), 4.14($ app t $J=6.2 \mathrm{~Hz}, 1 \mathrm{H}), 3.86(\mathrm{~d}, J=6.4 \mathrm{~Hz}, 2 \mathrm{H}), 2.74(\mathrm{~d}, J=$ $6.0 \mathrm{~Hz}, 1 \mathrm{H}$ ), 1.93 (ddd, $J=20.0,13.6,6.8 \mathrm{~Hz}, 1 \mathrm{H}$ ), 1.17 (d, $J=8.8 \mathrm{~Hz}, 6 \mathrm{H}), 0.92$ (s, 3H), 0.91 (s, 3H); ${ }^{13} \mathrm{C}$ NMR (100 MHz, $\left.\mathrm{CDCl}_{3}\right) \delta 177.34,136.19,117.54,77.93,70.80,46.75$, 
27.72, 22.60, 19.56, 19.04; IR (film) 3495, 2967, 1721, 1470, 1388, 1259, 1144, 1049, 994, $926 \mathrm{~cm}^{-1} ;[\alpha]^{27}=+23.8\left(c=1.12, \mathrm{CH}_{2} \mathrm{Cl}_{2}\right) ;$ MS (electrospray ionization) calculated for $\mathrm{C}_{11} \mathrm{H}_{20} \mathrm{O}_{3} \mathrm{Na}[\mathrm{M}+\mathrm{Na}]^{+}:$223.13, found 223.20.

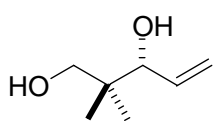

To a flame dried $1 \mathrm{~L}$ flask was added gem-dimethyl ester 9 (17 g, 84.9 mmol) and $425 \mathrm{~mL}$ of diethyl ether. The solution was cooled to $0{ }^{\circ} \mathrm{C}$, and then lithium aluminum hydride (4.83 g, $127 \mathrm{mmol}$ ) was added slowly in portions. The reaction was warmed to room temperature and stirred for 1 hour. The reaction was then recooled to $0{ }^{\circ} \mathrm{C}$ and quenched by the slow addition of water. The mixture was filtered through celite and washed successively with diethyl ether. The organic layer was washed with $1 \mathrm{M}$ sodium hydroxide, and the combine aqueous layers were extracted three times with diethyl ether. The combined organic layers were dried over $\mathrm{Na}_{2} \mathrm{SO}_{4}$ and concentrated in vacuo. Purification by flash column chromatography $\left(100 \% \mathrm{CH}_{2} \mathrm{Cl}_{2}\right)$ provided $10.7 \mathrm{~g}(97 \%)$ of the diol: ${ }^{1} \mathrm{H}$ NMR (400 MHz, $\mathrm{CDCl}_{3}$ ) $\delta 5.90$ (ddd, $J=17.2,10.4,6.8 \mathrm{~Hz}, 1 \mathrm{H}$ ), 5.23 (dt, $J=$ 10.4, 1.6, $1.2 \mathrm{~Hz}, 1 \mathrm{H}), 5.18$ (dq, $J=10.4,1.6,1.2 \mathrm{~Hz}, 1 \mathrm{H}$ ), 3.97 (d, $J=6.4 \mathrm{~Hz}, 1 \mathrm{H}), 3.48$ (q, $J=41.2,10.4 \mathrm{~Hz}, 2 \mathrm{H}$ ), 3.03 (bs, 1H), 2.99 (bs, 1H), 0.88 (s, 3H), 0.85 (s, 3H); ${ }^{13} \mathrm{C}$ NMR $\left(100 \mathrm{MHz}, \mathrm{CDCl}_{3}\right) \delta 137.46,116.75,80.76,71.80,38.27,22.28,18.96 ;$ IR (film) 3366, 2963, 1473, 1118, 1043, $925 \mathrm{~cm}^{-1} ;[\alpha]_{\mathrm{D}}^{26}=+20.0\left(c=0.46, \mathrm{CH}_{2} \mathrm{Cl}_{2}\right) ;$ MS (electrospray ionization) calculated for $\mathrm{C}_{7} \mathrm{H}_{14} \mathrm{O}_{2} \mathrm{Na}[\mathrm{M}+\mathrm{Na}]^{+}:$153.09, found 153.10 .

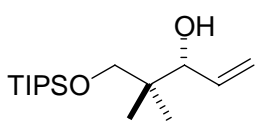

Triisopropylsilyl ether 10. A $1 \mathrm{~L}$ flask was charged with the diol from the previous experiment (10.7 g, $82.6 \mathrm{mmol}$ ) and $400 \mathrm{~mL}$ of dichloromethane. Triisopropylsilyl chloride 
(19.5 mL, $91.1 \mathrm{mmol})$ and imidazole $(11.2 \mathrm{~g}, 164 \mathrm{mmol})$ were added, and the resulting reaction mixture was stirred at room temperature overnight. The reaction was quenched by the addition of water, and the product was extracted twice with dichloromethane. The combined organic layers were dried over $\mathrm{Na}_{2} \mathrm{SO}_{4}$ and concentrated in vacuo. Purification by flash column chromatography (2\% to 5\% EtOAc/hexanes) provided $21.1 \mathrm{~g}$ (89\%) of silyl ether 10: ${ }^{1} \mathrm{H}$ NMR (400 MHz, $\mathrm{CDCl}_{3}$ ) $\delta 5.88$ (ddd, $\left.J=16.8,10.4,6.0 \mathrm{~Hz}, 1 \mathrm{H}\right), 5.26$ (dq, $J=$ 16.8, 2.0, $0.8 \mathrm{~Hz}, 1 \mathrm{H}), 5.15(\mathrm{dq}, J=10.8,2.0,0.8 \mathrm{~Hz}, 1 \mathrm{H}), 3.95$ (q, $J=6.0,4.4 \mathrm{~Hz}, 1 \mathrm{H})$, 3.79 (d, $J=4.4 \mathrm{~Hz}, 1 \mathrm{H}), 3.57$ (q, $J=43.6,9.6 \mathrm{~Hz}, 2 \mathrm{H}), 1.02-1.13$ (m, 21H), 0.88 (s, 3H), 0.86 (s, 3H); ${ }^{13} \mathrm{C}$ NMR (100 MHz, $\left.\mathrm{CDCl}_{3}\right) \delta 137.62,116.24,80.57,73.22,38.56,22.49$, 19.37, 17.96, 11.77; IR (film) 3491, 2944, 2867, 1467, 1385, 1365, 1249, 1097, 1065, 994, 921, 882, 807, $682 \mathrm{~cm}^{-1} ;[\alpha]_{\mathrm{D}}^{27}=+24.7\left(c=3.91, \mathrm{CH}_{2} \mathrm{Cl}_{2}\right) ;$ MS (electrospray ionization) calculated for $\mathrm{C}_{16} \mathrm{H}_{34} \mathrm{O}_{2} \mathrm{SiNa}[\mathrm{M}+\mathrm{Na}]^{+}$: 309.22, found 309.40.

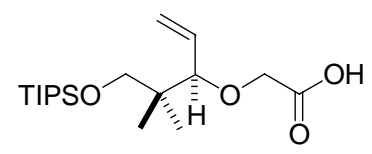

A $500 \mathrm{~mL}$ flask was charged with sodium hydride $(60 \%$ dispersion in mineral oil, 6.9 g, $172.5 \mathrm{mmol}$ ). The sodium hydride was washed three times with hexanes and dried under an atmosphere of argon. $30 \mathrm{~mL}$ of THF was added and the resultant heterogeneous solution was cooled to $0^{\circ} \mathrm{C}$. Bromoacetic acid (8.74g, $\left.62.9 \mathrm{mmol}\right)$ in $27 \mathrm{~mL}$ of THF was added via addition funnel. Following stirring at $0{ }^{\circ} \mathrm{C}$ for 30 minutes, alcohol 10 (16.4 g, $57.2 \mathrm{mmol}$ ) in $57 \mathrm{~mL}$ of dimethylformamide was added dropwise via addition funnel. After stirring for an additional 30 minutes at $0{ }^{\circ} \mathrm{C}$, the reaction was warmed to room temperature and stirred overnight. The heterogeneous solution was cooled to $0{ }^{\circ} \mathrm{C}$ and quenched slowly by the addition of water. The mixture was acidified to $\mathrm{pH} 2$ with $10 \%$ 
hydrochloric acid followed by extraction of the aqueous layer three times with ethyl acetate. The combined organic layers were washed with brine and dried over $\mathrm{Na}_{2} \mathrm{SO}_{4}$ followed by concentration in vacuo. Purification by flash column chromatography (20\% EtOAc/hexanes) afforded $19.3 \mathrm{~g}$ (98 \%) of the glycolic acid: ${ }^{1} \mathrm{H}$ NMR (400 MHz, $\mathrm{CDCl}_{3}$ ) $\delta 5.68$ (ddd, $J=18.8,10.4,8.4 \mathrm{~Hz}, 1 \mathrm{H}$ ), 5.37 (dd, $J=10.4,1.2 \mathrm{~Hz}, 1 \mathrm{H}$ ), 5.23 (dq, $J=17.2$, 1.6, $0.8 \mathrm{~Hz}, 1 \mathrm{H}), 4.02$ (q, $J=54.8,16.8 \mathrm{~Hz}, 2 \mathrm{H}), 3.73(\mathrm{~d}, J=8.4 \mathrm{~Hz}, 1 \mathrm{H}), 3.70$ (d, $J=9.6$ Hz, 1H), 3.40 (d, $J=9.6 \mathrm{~Hz}, 1 \mathrm{H}), 1.03-1.06$ (m, 21H), 0.88 (s, 3H), 0.86 (s, 3H); ${ }^{13} \mathrm{C}$ NMR $\left(100 \mathrm{MHz}, \mathrm{CDCl}_{3}\right) \delta 171.68,133.47,121.24,86.08,70.12,65.40,39.53,21.99,19.27$, 18.04, 11.97; IR (film) 2944, 2867, 1732, 1464, 1245, 1100, 998, 928, 882, $811 \mathrm{~cm}^{-1}$; $[\alpha]_{\mathrm{D}}^{27}=-1.85\left(c=1.96, \mathrm{CH}_{2} \mathrm{Cl}_{2}\right) ; \quad$ MS (electrospray ionization) calculated for $\mathrm{C}_{18} \mathrm{H}_{36} \mathrm{O}_{4} \mathrm{SiNa}[\mathrm{M}+\mathrm{Na}]^{+}:$367.23, found 367.50.

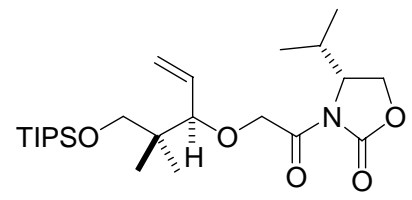

Acyl oxazolidinone 12. Into a three-neck $1 \mathrm{~L}$ flask was added the glycolic acid from above (19.2 g, $55.7 \mathrm{mmol})$, triethylamine (11.6 mL, $83.2 \mathrm{mmol})$, and $270 \mathrm{~mL}$ of diethyl ether. The solution was cooled to $-78{ }^{\circ} \mathrm{C}$, and pivaloyl chloride $(10.3 \mathrm{~mL}, 83.6 \mathrm{mmol})$ was added dropwise. After stirring ten minutes at $-78{ }^{\circ} \mathrm{C}$, the reaction was warmed to $0{ }^{\circ} \mathrm{C}$ for 1 hour followed by recooling to $-78{ }^{\circ} \mathrm{C}$.

Into a three-neck $500 \mathrm{~mL}$ flask fitted with an addition funnel and a mechanical stirrer was added $(R)$-4-isopropyl-oxazolidin-2-one $(11.5 \mathrm{~g}, 89.0 \mathrm{mmol})$ in $235 \mathrm{ml}$ of THF. After cooling to $-78{ }^{\circ} \mathrm{C}$, $n$-butyllithium (2.5 M solution in hexanes, $33.4 \mathrm{~mL}, 83.5 \mathrm{mmol}$ ) was added dropwise via addition funnel. The reaction was allowed to stir for 15 minutes at -78 ${ }^{\circ} \mathrm{C}$. The lithiated oxazolidinone was transferred via cannula into the mixed anhydride 
followed by warming to $0{ }^{\circ} \mathrm{C}$ for 1 hour. The reaction was quenched with saturated $\mathrm{NH}_{4} \mathrm{Cl}$. The solution was extracted twice with ethyl acetate, and the combined organic extracts were dried over $\mathrm{Na}_{2} \mathrm{SO}_{4}$ and concentrated in vacuo. Purification by flash chromatography (10\% to $20 \%$ EtOAc/hexanes) afforded $24.9 \mathrm{~g}(98 \%)$ of $12:{ }^{1} \mathrm{H}$ NMR $\left(400 \mathrm{MHz}, \mathrm{CDCl}_{3}\right) \delta 5.76$ (ddd, $J=18.8,10.4,8.4 \mathrm{~Hz}, 1 \mathrm{H}$ ), 5.24 (dd, $J=10.4,2.0 \mathrm{~Hz}, 1 \mathrm{H}$ ), 5.19 (app dd, $J=17.2,1.2$ Hz, 1H), 4.58 (q, $J=41.2,18.0 \mathrm{~Hz}, 2 \mathrm{H}), 4.39$ (dt, $J=8.4,3.6 \mathrm{~Hz}, 1 \mathrm{H}), 4.29$ (t, $J=9.2 \mathrm{~Hz}$, 1H), 4.22 (dd, $J=9.2,3.2 \mathrm{~Hz}, 1 \mathrm{H}$ ), 3.69 (d, $J=8.4 \mathrm{~Hz}, 1 \mathrm{H}$ ), 3.49 (q, $J=58.0,9.2 \mathrm{~Hz}, 2 \mathrm{H}$ ), 2.40 (ddq, $J=14.0,10.8,7.2,4.0 \mathrm{~Hz}, 1 \mathrm{H}), 1.00-1.06$ (m, 21H), 0.97 (s, 3H), 0.86 (dd, $J=$ 19.6, $6.8 \mathrm{~Hz}, 6 \mathrm{H}), 0.85$ (s, 3H); ${ }^{13} \mathrm{C}$ NMR $\left(100 \mathrm{MHz}, \mathrm{CDCl}_{3}\right) \delta 170.90,154.35,135.50$, 119.79, 86.83, 70.02, 68.84, 64.58, 58.57, 40.40, 28.55, 26.85, 21.37, 20.64, 18.45, 12.38; IR (film) 2962, 2867, 1785, 1722, 1465, 1388, 1363, 1302, 1257, 1207, 1100, 1060, 997, 882, 811, 717, $681 \mathrm{~cm}^{-1} ;[\alpha]_{\mathrm{D}}^{27}=-35.2\left(c=3.40, \mathrm{CH}_{2} \mathrm{Cl}_{2}\right) ;$ MS (electrospray ionization) calculated for $\mathrm{C}_{24} \mathrm{H}_{45} \mathrm{NO}_{5} \mathrm{SiNa}[\mathrm{M}+\mathrm{Na}]^{+}:$478.30, found 478.50 .

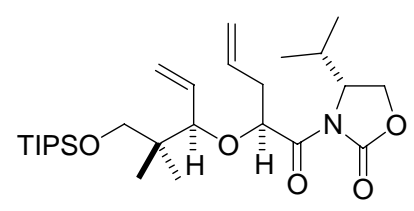

A three-neck $1 \mathrm{~L}$ flask equipped with an addition funnel and a low temperature thermometer was charged with $\mathrm{NaN}\left(\mathrm{SiMe}_{3}\right)_{2}(0.53 \mathrm{M}, 67.0 \mathrm{~mL}, 35.5 \mathrm{mmol})$ in $170 \mathrm{~mL}$ of THF. Upon cooling the solution to $-78{ }^{\circ} \mathrm{C}$, glycolate $12(13.5 \mathrm{~g}, 29.6 \mathrm{mmol})$ in $115 \mathrm{~mL}$ of THF was added dropwise via addition funnel at such a rate to maintain the reaction temperature below $-65{ }^{\circ} \mathrm{C}$. After stirring at $-78{ }^{\circ} \mathrm{C}$ for 1 hour, allyl iodide (13.5 $\mathrm{mL}, 147.6 \mathrm{mmol}$ ) was added dropwise via syringe. After stirring 15 minutes at $-78{ }^{\circ} \mathrm{C}$, the reaction was slowly warmed to $-45^{\circ} \mathrm{C}$ and held at that temperature for 1.5 hour. The reaction was quenched slowly with saturated $\mathrm{NH}_{4} \mathrm{Cl}$ and warmed to room temperature. The 
reaction was extracted three times with ethyl acetate. The combined organic layers were dried over $\mathrm{Na}_{2} \mathrm{SO}_{4}$ and concentrated in vacuo. Purification by flash column chromatography (5\% EtOAc/hexanes) afforded $12.0 \mathrm{~g}(82 \%)$ of the alkylation product: ${ }^{1} \mathrm{H}$ NMR (400 MHz, $\mathrm{CDCl}_{3}$ ) $\delta 5.86$ (app ddt, $J=17.2,10.4,6.8 \mathrm{~Hz}, 1 \mathrm{H}$ ), 5.71 (ddd, $J=17.2,10.0,8.4 \mathrm{~Hz}, 1 \mathrm{H}$ ), 5.24 (dd, $J=10.4,2.0 \mathrm{~Hz}, 1 \mathrm{H}$ ), 5.19 (q, $J=6.8,4.8 \mathrm{~Hz}, 1 \mathrm{H}$ ), 5.09 (app dd, $J=10.0,1.6 \mathrm{~Hz}$, 1H), 5.01-5.04 (m, 2H), 4.45 (dd, $J=8.4,3.6 \mathrm{~Hz}, 1 \mathrm{H}), 4.26$ (t, $J=8.8 \mathrm{~Hz}, 1 \mathrm{H}), 4.19$ (dd, $J=$ 9.2, 3.2 Hz, 1H), 3.48 (q, $J=63.2,9.2 \mathrm{~Hz}, 2 \mathrm{H}), 3.48$ (d, $J=8.8 \mathrm{~Hz}, 1 \mathrm{H}), 2.51-2.57$ (m, 1H), 2.39-2.46 (m, 1H), 2.29 (ddq, $J=14.0,10.8,6.8,3.6 \mathrm{~Hz}, 1 \mathrm{H}), 1.01-1.10$ (m, 21H), 1.00 (s, 3H), 0.86 (dd, $J=31.6,6.8 \mathrm{~Hz}, 6 \mathrm{H}), 0.84(\mathrm{~s}, 3 \mathrm{H}) ;{ }^{13} \mathrm{C} \mathrm{NMR}\left(100 \mathrm{MHz}, \mathrm{CDCl}_{3}\right) \delta 172.46$, 153.55, 135.68, 133.53, 119.49, 117.51, 84.92, 73.39, 69.63, 63.76, 58.18, 40.14, 37.95, 28.30, 21.21, 20.51, 18.07, 14.69, 12.00; IR (film) 2962, 2867, 1784, 1715, 1465, 1388, $1301,1204,1099,996,924,882,803 \mathrm{~cm}^{-1} ; \quad[\alpha]_{\mathrm{D}}^{27}=-50.6\left(c=0.72, \mathrm{CH}_{2} \mathrm{Cl}_{2}\right) ; \quad \mathrm{MS}$ (electrospray ionization) calculated for $\mathrm{C}_{27} \mathrm{H}_{49} \mathrm{NO}_{5} \mathrm{SiNa}[\mathrm{M}+\mathrm{Na}]^{+}$: 518.33, found 518.50.

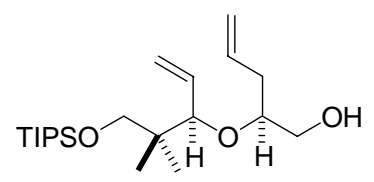

Alcohol 13. To a $500 \mathrm{~mL}$ flask was added the alkylation product from the previous reaction (8.6 g, $17.3 \mathrm{mmol})$, anhydrous methanol (1.1 mL, $27.2 \mathrm{mmol})$, and $170 \mathrm{~mL}$ of diethyl ether. The reaction was cooled to $0^{\circ} \mathrm{C}$ followed by addition of lithium borohydride (2.0 M in THF, $13 \mathrm{~mL}, 26.0 \mathrm{mmol}$ ) dropwise via syringe. After stirring at $0{ }^{\circ} \mathrm{C}$ for 1 hour, the reaction was slowly quenched by the addition of saturated potassium/sodium tartrate solution. The mixture was warmed to room temperature and stirred vigorously overnight. The aqueous layer was extracted three times with ethyl acetate. The combined organic layers were dried over $\mathrm{Na}_{2} \mathrm{SO}_{4}$ and concentrated in vacuo. Purification by flash column chromatography (2\% 
to $5 \%$ EtOAc/hexanes) afforded $4.81 \mathrm{~g}(75 \%)$ of alcohol 13: ${ }^{1} \mathrm{H}$ NMR (400 MHz, $\left.\mathrm{CDCl}_{3}\right)$ $\delta 5.74$ (ddt, $J=14.0,10.0,7.2 \mathrm{~Hz}, 1 \mathrm{H}$ ), 5.70 (ddd, $J=17.6,8.8,7.2 \mathrm{~Hz}, 1 \mathrm{H}$ ), 5.22 (dd, $J=$ 10.0, $1.6 \mathrm{~Hz}, 1 \mathrm{H}), 5.16$ (dq, $J=17.2,2.0,0.8 \mathrm{~Hz}, 1 \mathrm{H}), 4.96-5.04$ (m, 2H), 3.79 (q, $J=36.8$, 8.8 Hz, 2H), 3.61-3.66 (m, 1H), 3.39-3.49 (m, 2H), 3.32 (d, $J=9.6 \mathrm{~Hz}, 1 \mathrm{H}), 2.59$ (q, $J=7.6$, $6.4 \mathrm{~Hz}, 1 \mathrm{H}), 2.12-2.27$ (m, 2H), 1.03-1.16 (m, 21H), 0.83 (s, 3H), 0.82 (s, 3H); ${ }^{13} \mathrm{C}$ NMR $\left(100 \mathrm{MHz}, \mathrm{CDCl}_{3}\right) \delta 136.27,134.94,118.82,116.62,82.87,75.77,69.89,63.96,39.65$, 36.76, 21.99, 19.42, 18.02, 12.06; IR (film) 3467, 3077, 2944, 2868, 1641, 1464, 1391, 1096, 997, 923, 882, 798, $682 \mathrm{~cm}^{-1} ;[\alpha]^{27}=+4.30\left(c=2.91, \mathrm{CH}_{2} \mathrm{Cl}_{2}\right)$; MS (electrospray ionization) calculated for $\mathrm{C}_{21} \mathrm{H}_{42} \mathrm{O}_{3} \mathrm{SiNa}[\mathrm{M}+\mathrm{Na}]^{+}$: 393.28, found 393.40.

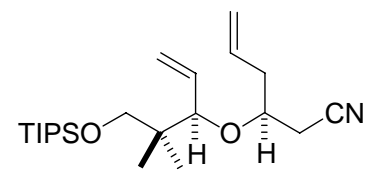

A $100 \mathrm{~mL}$ flask was charged with alcohol 13 (2.01 g, $5.42 \mathrm{mmol})$ and 55 $\mathrm{mL}$ of toluene. Diethylazodicarboxylate $(1.30 \mathrm{~mL}, 8.25 \mathrm{mmol})$, triphenylphosphine (2.13 g, $8.12 \mathrm{mmol})$, and acetone cyanohydrin $(5.10 \mathrm{~mL}, 55.8 \mathrm{mmol})$ were added to the solution. The reaction was heated at $70{ }^{\circ} \mathrm{C}$ for 18 hours at which time thin layer chromatography analysis revealed only $50 \%$ conversion. The reaction mixture was cooled to room temperature, and additional diethylazodicarboxylate $(2.60 \mathrm{~mL}, 16.5 \mathrm{mmol})$ and triphenylphosphine ( $4.26 \mathrm{~g}, 16.2 \mathrm{mmol}$ ) were added. The reaction was then reheated to 70 ${ }^{\circ} \mathrm{C}$ and stirred for an additional 5 hours. The mixture was then cooled to room temperature and quenched with water. The aqueous layer was extracted three times with dichloromethane and the combined organic layers were dried over $\mathrm{Na}_{2} \mathrm{SO}_{4}$. Concentration in vacuo provided a residue that was diluted with dichloromethane. 30\% hydrogen peroxide was added to oxidize the remaining triphenylphosphine, and the mixture was stirred 1 hour 
at room temperature. Saturated sodium thiosulfate was then carefully added until the mixture no longer reacted. The layers were separated and the organic layer was dried over $\mathrm{Na}_{2} \mathrm{SO}_{4}$. Concentration in vacuo and purification by flash column chromatography (2\% EtOAc/hexanes) provided $1.84 \mathrm{~g}$ (89\%) of the nitrile: ${ }^{1} \mathrm{H}$ NMR (400 $\left.\mathrm{MHz}, \mathrm{CDCl}_{3}\right) \delta 5.67-$ 5.78 (m, 2H), 5.24 (app dd, $J=10.0,1.2 \mathrm{~Hz}, 1 \mathrm{H}), 5.06-5.16(\mathrm{~m}, 3 \mathrm{H}), 3.68$ (d, $J=8.4 \mathrm{~Hz}$, 1H), 3.66 (app q, $J=11.6,6.0 \mathrm{~Hz}, 1 \mathrm{H}), 3.45$ (q, $J=36.0,9.2 \mathrm{~Hz}, 2 \mathrm{H}), 2.46$ (d, $J=5.2 \mathrm{~Hz}$, 2H), 2.34-2.38 (m, 2H), 1.02-1.12 (m, 21H), 0.89 (s, 3H), 0.81 (s, 3H); ${ }^{13} \mathrm{C}$ NMR (100 $\left.\mathrm{MHz}, \mathrm{CDCl}_{3}\right) \delta 135.68,133.17,119.06,118.42,117.57,83.45,71.30,69.52,39.89,30.06$, 21.42, 21.09, 20.67, 18.09, 12.02; IR (film) 3079, 2944, 2867, 1643, 1464, 1259, 1095, 997, 923, 882, 800, $681 \mathrm{~cm}^{-1} ;[\alpha]^{27}=-16.2\left(c=1.76, \mathrm{CH}_{2} \mathrm{Cl}_{2}\right) ; \mathrm{MS}$ (electrospray ionization) calculated for $\mathrm{C}_{22} \mathrm{H}_{41} \mathrm{NO}_{3} \mathrm{SiNa}[\mathrm{M}+\mathrm{Na}]^{+}$: 402.28, found 402.40 .

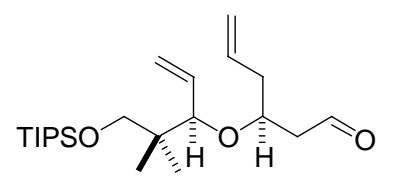

Aldehyde 14. A $100 \mathrm{~mL}$ flask was charged with nitrile from above(862 mg, $2.27 \mathrm{mmol})$ and $23 \mathrm{~mL}$ of dichloromethane. The solution was cooled to $-78{ }^{\circ} \mathrm{C}$ followed by dropwise addition of diisobutylaluminum hydride (1.0 M in heptane, $4.5 \mathrm{~mL}, 4.50 \mathrm{mmol})$. After stirring at $-78{ }^{\circ} \mathrm{C}$ for 1 hour, the reaction was quenched with saturated potassium/sodium tartrate solution. The mixture was warmed to room temperature and stirred for 3 hours. The layers were separated and the aqueous layer was extracted three times with dichloromethane. The combined organic layers were dried over $\mathrm{Na}_{2} \mathrm{SO}_{4}$ and concentrated in vacuo. The crude aldehyde was filtered through a small plug of silica gel eluting with dichloromethane to provide 2.73g (87\%) of aldehyde 14. The aldehyde was used immediately in the following aldol reaction: ${ }^{1} \mathrm{H}$ NMR (400 MHz, $\left.\mathrm{CDCl}_{3}\right) \delta 9.80(\mathrm{t}, J=2.2 \mathrm{~Hz}, 1 \mathrm{H}), 5.69-5.79(\mathrm{~m}, 2 \mathrm{H})$, 
5.22 (dd, $J=10.0,1.6 \mathrm{~Hz}, 1 \mathrm{H}), 5.16$ (dq, $J=17.2,2.0,0.8 \mathrm{~Hz}, 1 \mathrm{H}$ ), 5.04 (s, $1 \mathrm{H}), 4.99-5.02$

(m, 1H), 3.90 (dq, $J=11.6,11.6,6.0 \mathrm{~Hz}, 1 \mathrm{H}$ ), 3.67 (d, $J=8.4 \mathrm{~Hz}, 1 \mathrm{H}$ ), 3.42 (q, $J=28.4,9.6$ Hz, 2H), 2.49-2.61 (m, 2H), 2.20-2.34 (m, 2H), 1.01-1.06 (m, 21H), 0.86 (s, 3H), 0.78 (s, $3 \mathrm{H})$.

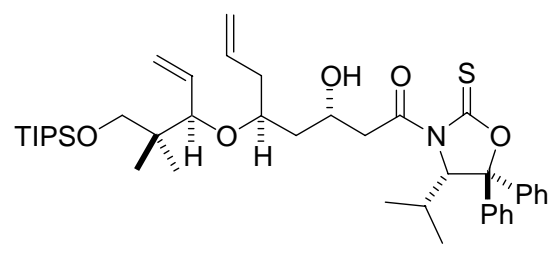

To a $250 \mathrm{~mL}$ flask was added acetyl oxazolidinethione 15 (4.8 g, 14.1 mmol) and $35 \mathrm{~mL}$ of dichloromethane. The solution was cooled to $0{ }^{\circ} \mathrm{C}$ followed by dropwise addition of titanium tetrachloride $(1.55 \mathrm{~mL}, 14.1 \mathrm{mmol})$ to produce an orange solution. After stirring for 15 minutes at $0{ }^{\circ} \mathrm{C}$, (-)-sparteine (3.2 ml, $\left.13.9 \mathrm{mmol}\right)$ was added dropwise producing a dark red solution. The reaction was stirred 20 minutes at $0{ }^{\circ} \mathrm{C}$ and then was cooled to $-78{ }^{\circ} \mathrm{C}$. $N$-Methylpyrrolidinone $(1.4 \mathrm{~mL}, 14.5 \mathrm{mmol})$ was added dropwise, and the resulting solution was stirred 10 minutes at $-78{ }^{\circ} \mathrm{C}$ at which time aldehyde 14 (2.7 g, $7.1 \mathrm{mmol})$ in $12 \mathrm{~mL}$ of dichloromethane was added dropwise. After stirring at -78 ${ }^{\circ} \mathrm{C}$ for 3 hours, the reaction was quenched with half-saturated $\mathrm{NH}_{4} \mathrm{Cl}$, and the mixture was warmed to room temperature. The aqueous layer was extracted three times with dichloromethane, and the combined organic layers were dried over $\mathrm{Na}_{2} \mathrm{SO}_{4}$. Concentration in vacuo followed by purification by flash column chromatography (5\% to $10 \%$ to $17.5 \%$ EtOAc/hexanes) provided $7.74 \mathrm{~g}$ of the aldol product as an inseparable mixture with the starting acetyl oxazolidinethione. An analytical sample was prepared by preparation of the TMS ether of the aldol adduct, separation of the auxiliary contaminant by chromatography and then cleavage of the TMS ether. ${ }^{1} \mathrm{H}$ NMR $\left(400 \mathrm{MHz}, \mathrm{CDCl}_{3}\right) \delta$ 7.41-7.47 (m, 4H), 
7.24-7.34 (m, 6H), 5.70-5.82 (m, 2H), 5.61 (d, $J=3.6 \mathrm{~Hz}, 1 \mathrm{H}), 5.17$ (d, $J=2.8 \mathrm{~Hz}, 1 \mathrm{H}$ ), 5.14 (dd, $J=11.2,2.0 \mathrm{~Hz}, 1 \mathrm{H}$ ), 5.01 (app d, $J=7.6 \mathrm{~Hz}, 1 \mathrm{H}$ ), 4.98 (s, 1H), 4.20-4.25 (m, 1H), 3.71 (d, $J=8.0 \mathrm{~Hz}, 1 \mathrm{H}$ ), 3.58-3.65 (m, 2H), 3.44 (q, $J=36.8,9.2 \mathrm{~Hz}, 2 \mathrm{H}$ ), 3.10 (d, $J=$ $2.8 \mathrm{~Hz}, 1 \mathrm{H}$ ), 2.99 (dd, $J=17.2,8.4 \mathrm{~Hz}, 1 \mathrm{H}), 2.25$ (t, $J=6.0 \mathrm{~Hz}, 2 \mathrm{H}), 1.98-2.06$ (m, 1H), 1.73 (ddd, $J=14.4,9.6,6.0 \mathrm{~Hz}, 1 \mathrm{H}$ ), 1.52 (ddd, $J=14.0,6.4,2.8 \mathrm{~Hz}, 1 \mathrm{H}$ ), 1.02-1.08 (m, 21H), 0.87 (s, 3H), 0.81 (dd, $J=34.0,7.2 \mathrm{~Hz}, 6 \mathrm{H}), 0.78$ (s, 3H); ${ }^{13} \mathrm{C}$ NMR (100 MHz, $\left.\mathrm{CDCl}_{3}\right) \delta 184.67,172.94,141.49,137.38,136.95,135.10,128.90,128.71,128.39,128.08$, 126.05, 125.32, 117.68, 116.67, 93.30, 82.48, 74.70, 69.66, 68.08, 65.95, 44.61, 40.12, 39.79, 39.05, 30.01, 21.53, 21.02, 20.56, 18.10, 16.87, 12.01; IR (film) 3534, 3071, 2943, 2866, 1689, 1640, 1494, 1465, 1450, 1395, 1336, 1242, 1169, 1095, 996, 972, 911, 882, 810, 735, 703, $644 \mathrm{~cm}^{-1} ;[\alpha]_{\mathrm{D}}^{27}=-76.6\left(c=6.74, \mathrm{CH}_{2} \mathrm{Cl}_{2}\right) ;$ MS (electrospray ionization) calculated for $\mathrm{C}_{42} \mathrm{H}_{64} \mathrm{NO}_{5} \mathrm{SSi}[\mathrm{M}+\mathrm{H}]^{+}:$722.43, found 722.70 .

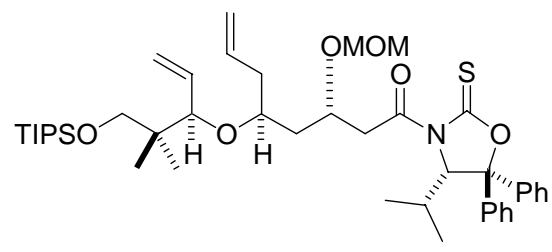

Methoxymethyl ether 16. A $500 \mathrm{~mL}$ flask was charged with the aldol adduct (7.06 mmol) and $140 \mathrm{~mL}$ of dichloromethane. The solution was cooled to $0{ }^{\circ} \mathrm{C}$ followed by addition of diisopropylethylamine (16.0 mL, $91.85 \mathrm{mmol})$, chloromethylmethyl ether $(9.1 \mathrm{~mL}, 70.7$ mmol), and dimethylaminopyridine (86 $\mathrm{mg}, 0.70 \mathrm{mmol}$ ). The reaction mixture was then warmed to room temperature and heated further to reflux. After stirring for 18 hours, the reaction was cooled to room temperature and quenched by the addition of water. The product was extracted three times with dichloromethane, and the combined organic layers were dried over $\mathrm{Na}_{2} \mathrm{SO}_{4}$. Concentration in vacuo followed by purification by flash column 
chromatography (10\% EtOAc/hexanes) provided $6.6 \mathrm{~g}$ of the methoxymethyl ether $\mathbf{1 6}$ as an inseparable mixture with the acetyl oxazolidinethione: ${ }^{1} \mathrm{H} \mathrm{NMR}\left(400 \mathrm{MHz}, \mathrm{CDCl}_{3}\right) \delta$ 7.377.49 (m, 4H), 7.26-7.36 (m, 6H), 5.81 (ddt, $J=17.2,10.0,6.8 \mathrm{~Hz}, 1 \mathrm{H}$ ), 5.70 (ddd, $J=17.6$, 10.4, $8.4 \mathrm{~Hz}, 1 \mathrm{H}$ ), 5.59 (d, $J=4.0 \mathrm{~Hz}, 1 \mathrm{H}) 5.15$ (dd, $J=10.4,2.0 \mathrm{~Hz}, 1 \mathrm{H}$ ), 5.10 (dd, $J=$ 17.6, $2.0 \mathrm{~Hz}, 1 \mathrm{H}), 4.96-5.04$ (m, 2H), 4.45 (q, $J=39.6,7.2 \mathrm{~Hz}, 2 \mathrm{H}), 4.06-4.13$ (m, 1H), 3.62 (d, $J=8.4 \mathrm{~Hz}, 1 \mathrm{H}$ ), 3.54 (dd, $J=18.0,6.4 \mathrm{~Hz}, 1 \mathrm{H}$ ), 3.44-3.50 (m, 1H), 3.43 (q, $J=32.8,9.2$ Hz, 2H), 3.33 (dd, $J=17.6,5.6$ Hz, 1H), 3.15 (s, 3H), 2.26-2.33 (m, 1H), 2.12-2.19 (m, 1H), 1.97 (m, 1H), 1.86 (ddd, $J=12.4,8.4,3.6 \mathrm{~Hz}, 1 \mathrm{H}$ ), 1.52 (ddd, $J=12.4,8.4,4.0 \mathrm{~Hz}, 1 \mathrm{H}$ ), 1.01-1.08 (m, 21H), 0.86 (s, 3H), 0.79 (dd, $J=30.4,7.2 \mathrm{~Hz}, 6 \mathrm{H}), 0.79$ (s, 3H); ${ }^{13} \mathrm{C}$ NMR $\left(100 \mathrm{MHz}, \mathrm{CDCl}_{3}\right) \delta 184.73,171.61,141.69,137.52,135.56,128.87,128.64,128.39$, 128.06, 126.13, 125.43, 117.89, 116.34, 96.06, 93.15, 82.46, 72.56, 71.62, 69.62, 68.21, 55.62, 43.10, 39.92, 39.00, 30.34, 22.62, 21.56, 21.19, 20.46, 18.13, 17.01, 12.06; IR (film) 2943, 2866, 1702, 1450, 1366, 1336, 1169, 1100, 1036, 996, 918, 882, 810, $752 \mathrm{~cm}^{-1}$; $[\alpha]_{D}^{26}=-87.2\left(c=3.26, \mathrm{CH}_{2} \mathrm{Cl}_{2}\right) ; \quad$ MS (electrospray ionization) calculated for $\mathrm{C}_{44} \mathrm{H}_{67} \mathrm{NO}_{6} \mathrm{SSiNa}[\mathrm{M}+\mathrm{Na}]^{+}:$788.44, found 788.50.

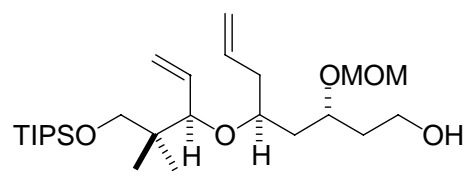

To a $250 \mathrm{~mL}$ flask equipped with an addition funnel was added the acyl oxazolidinethione 16 (6.6 g as mixture), anhydrous methanol (4.0 mL, $99 \mathrm{mmol})$ and $100 \mathrm{~mL}$ of diethyl ether. After cooling to $0{ }^{\circ} \mathrm{C}$, lithium borohydride (2.0 M in THF, $49 \mathrm{~mL}, 98 \mathrm{mmol}$ ) was added dropwise to the solution. The reaction was stirred 5 minutes at $0{ }^{\circ} \mathrm{C}$ and then warmed to room temperature. After stirring for 1.5 hours at room temperature, the reaction was quenched by the addition of saturated potassium/sodium tartrate solution. The resulting 
mixture was stirred vigorously overnight. The product was extracted three times with diethyl ether, and the combined organic layers were dried over $\mathrm{Na}_{2} \mathrm{SO}_{4}$. Concentration in vacuo provided a residue that was diluted with hexanes, and the solution was cooled to $0{ }^{\circ} \mathrm{C}$ allowing crystallization of the free oxazolidinethione auxiliary. The precipitate was filtered and washed with cold hexanes. The mother liquor was concentrated in vacuo, and purification by flash column chromatography (25\% EtOAc/hexanes) provided 2.05 g (61\% over three steps) of the alcohol: ${ }^{1} \mathrm{H}$ NMR $\left(400 \mathrm{MHz}, \mathrm{CDCl}_{3}\right) \delta 5.73-5.83(\mathrm{~m}, 1 \mathrm{H}), 5.72$ (ddd, $J=17.2,10.4,8.4 \mathrm{~Hz}, 1 \mathrm{H}$ ), 5.16 (dq, $J=10.4,2.0,0.8 \mathrm{~Hz}, 1 \mathrm{H}$ ), 5.12 (dq, $J=17.2$, 2.0, $0.8 \mathrm{~Hz}, 1 \mathrm{H}$ ), 5.00 (app d, $J=4.8 \mathrm{~Hz}, 1 \mathrm{H}$ ), 4.97 (s, 1H), 4.60 (s, 2H), 3.80-3.86 (m, 1H), 3.74-3.78 (m, 1H), 3.64-3.70 (m, 1H), 3.61 (d, $J=8.4 \mathrm{~Hz}, 1 \mathrm{H}$ ), 3.45 (dd, $J=6.8,5.6 \mathrm{~Hz}$, 1H), 3.39-3.43 (m, 2H), 3.35 (s, 3H), 2.40 (bs, 1H), 2.15-2.29 (m, 2H), 1.78-1.87 (m, 2H), 1.62-1.70 (m, 1H), 1.50 (ddd, $J=12.8,7.2,5.6 \mathrm{~Hz}, 1 \mathrm{H}), 1.00-1.06$ (m, 21H), 0.89 (s, 3H), 0.78 (s, 3H); ${ }^{13} \mathrm{C}$ NMR (100 MHz, $\left.\mathrm{CDCl}_{3}\right) \delta 137.21,135.36,117.91,116.50,95.86,83.14$, 73.69, 72.84, 69.69, 59.69, 55.83, 40.07, 39.46, 38.69, 37.30, 20.88, 20.77, 18.15, 12.03; IR (film) 3434, 3075,2944, 2867, 1640, 1464, 1384, 1151, 1098, 1034, 920, 882, 810, $681 \mathrm{~cm}^{-1}$; $[\alpha]^{28}=+14.2\left(c=3.06, \mathrm{CH}_{2} \mathrm{Cl}_{2}\right) ; \quad$ MS (electrospray ionization) calculated for $\mathrm{C}_{26} \mathrm{H}_{52} \mathrm{O}_{5} \mathrm{SiNa}[\mathrm{M}+\mathrm{Na}]^{+}:$495.35, found 495.50.

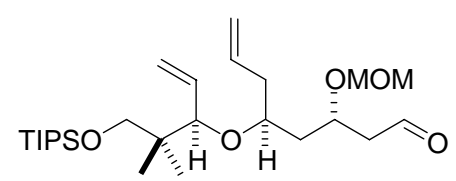

Aldehyde 6. A three-neck $100 \mathrm{~mL}$ flask equipped with a mechanical stirrer, low temperature thermometer, and an addition funnel was charged with oxalyl chloride (2.0 M in dichloromethane, $2.4 \mathrm{~mL}, 4.8 \mathrm{mmol}$ ) in $10 \mathrm{~mL}$ of dichloromethane. After the solution was cooled to $-78{ }^{\circ} \mathrm{C}$, dimethyl sulfoxide $(0.685 \mathrm{~mL}, 9.65 \mathrm{mmol})$ in $5 \mathrm{~mL}$ of dichloromethane 
was added dropwise via an addition funnel at such a rate as to maintain the reaction temperature below $-65^{\circ} \mathrm{C}$. After stirring at $-78{ }^{\circ} \mathrm{C}$ for 30 minutes, the primary alcohol from the previous reaction ( $2.0 \mathrm{~g}, 4.23 \mathrm{mmol})$ in $20 \mathrm{~mL}$ of dichloromethane was added dropwise via an addition funnel at such a rate as to maintain the reaction temperature below $-65{ }^{\circ} \mathrm{C}$. After stirring for an additional 20 minutes at $-78{ }^{\circ} \mathrm{C}$, triethylamine $(3.0 \mathrm{~mL}, 21.5 \mathrm{mmol})$ was added dropwise maintaining a temperature below $-65^{\circ} \mathrm{C}$. The reaction was allowed to stir five minutes at $-78{ }^{\circ} \mathrm{C}$ and then warmed to room temperature upon removal of the cold bath. The reaction was quenched with water and the mixture was extracted twice with ethyl acetate. The combined organic layers were dried over $\mathrm{Na}_{2} \mathrm{SO}_{4}$ and concentrated in vacuo. The crude aldehyde was filtered through a small plug of silica gel eluting with dichloromethane to provide $1.84 \mathrm{~g}(92 \%)$ of aldehyde 6 . The aldehyde was used immediately in the following aldol reaction: ${ }^{1} \mathrm{H}$ NMR $\left(400 \mathrm{MHz}, \mathrm{CDCl}_{3}\right) \delta 9.76(\mathrm{t}, J=2.0$ Hz, 1H), 5.79 (ddt, $J=17.6,10.8,7.2 \mathrm{~Hz}, 1 \mathrm{H}$ ), 5.72 (ddd, $J=17.2,10.4,8.4 \mathrm{~Hz}, 1 \mathrm{H}$ ), 5.18 (dd, $J=10.4,2.0 \mathrm{~Hz}, 1 \mathrm{H}), 5.12$ (ddd, $J=17.2,2.0,0.8 \mathrm{~Hz}, 1 \mathrm{H}), 5.01-5.04$ (m, 1H), 4.99 (s, 1H), 4.60 (s, 2H), 4.14 (ddt, $J=11.6,8.0,5.6 \mathrm{~Hz}, 1 \mathrm{H}$ ), 3.63 (d, $J=8.4 \mathrm{~Hz}, 1 \mathrm{H}$ ), 3.47-3.53 (m, 1H), 3.42 (q, $J=16.8,9.2 \mathrm{~Hz}, 2 \mathrm{H}), 3.28-3.31$ (m, 3H), 2.55-2.66 (m, 2H), 2.18-2.32 (m, 2H), 1.90 (ddd, $J=12.4,7.6,4.4 \mathrm{~Hz}, 1 \mathrm{H}$ ), 1.54 (ddd, $J=12.4,7.2,5.2 \mathrm{~Hz}, 1 \mathrm{H}$ ), 1.02-1.07 (m, 21H), 0.88 (s, 3H), $0.78(\mathrm{~s}, 3 \mathrm{H})$.

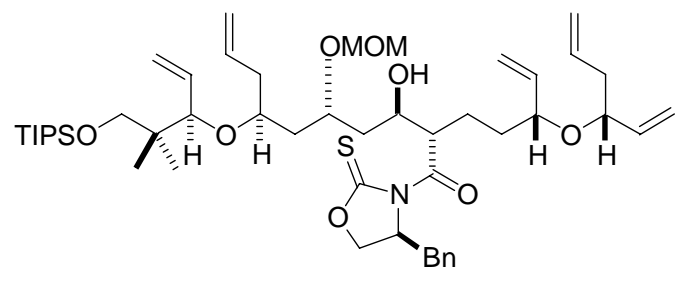

Aldol adduct 22. A $100 \mathrm{~mL}$ flask was charged with acyl oxazolidinethione 7 (1.54 g, 3.85 $\mathrm{mmol}$ ) and $40 \mathrm{~mL}$ of dichloromethane. The solution was cooled to $-78{ }^{\circ} \mathrm{C}$ followed by 
dropwise addition of titanium tetrachloride $(0.425 \mathrm{~mL}, 3.87 \mathrm{mmol})$ to produce an orange solution. After stirring 20 minutes at $-78{ }^{\circ} \mathrm{C}$, (-)-sparteine $(0.890 \mathrm{~mL}, 3.87 \mathrm{mmol})$ was added dropwise producing a dark red solution. The solution was stirred 1 hour at $-78{ }^{\circ} \mathrm{C}$, and then distilled $N$-methylpyrrolidinone $(0.370 \mathrm{~mL}, 3.84 \mathrm{mmol})$ was added dropwise. After stirring 10 minutes at $-78{ }^{\circ} \mathrm{C}$, aldehyde $6(1.84 \mathrm{~g}, 3.91 \mathrm{mmol})$ in $10 \mathrm{~mL}$ of dichloromethane was added dropwise. The resulting reaction mixture was stirred 30 minutes at $-78{ }^{\circ} \mathrm{C}$, and then warmed to $0{ }^{\circ} \mathrm{C}$. After stirring at $0{ }^{\circ} \mathrm{C}$ for 1 hour, the reaction was quenched by the addition of half-saturated $\mathrm{NH}_{4} \mathrm{Cl}$, and the mixture was warmed to room temperature. The aqueous layer was extracted three times with dichloromethane, and the combined organic layers were dried over $\mathrm{Na}_{2} \mathrm{SO}_{4}$. Concentration in vacuo followed by purification by flash column chromatography ( $5 \%$ to $10 \%$ to $17.5 \%$ to $25 \%$ EtOAc/hexanes) provided $2.75 \mathrm{~g}(81 \%)$ of aldol adduct 22: ${ }^{1} \mathrm{H}$ NMR (400 MHz, $\left.\mathrm{CDCl}_{3}\right) \delta$ 7.29-7.34 (m, 2H), 7.18-7.27 (m, 3H), 5.68-5.84 (m, 3H), 5.55-5.66 (m, 2H), 5.15-5.20 (m, 4H), 5.03-5.12 (m, 3H), 4.89-5.01 (m, 5H), 4.59 (q, $J=14.4,6.4 \mathrm{~Hz}, 2 \mathrm{H}), 4.28$ (dd, $J=9.2,2.4 \mathrm{~Hz}, 1 \mathrm{H})$, 4.17-4.22 (m, 2H), 3.87-3.89 (m, 1H), 3.73-3.81 (m, 2H), 3.59 (d, J = 8.4 Hz, 1H), 3.39-3.45 (m, 3H), 3.34 (s, 3H), 3.30 (dd, $J=13.6,3.6 \mathrm{~Hz}, 1 \mathrm{H}$ ), 3.23 (d, $J=3.2 \mathrm{~Hz}, 1 \mathrm{H}$ ), 2.69 (dd, $J=$ 13.2, $10.8 \mathrm{~Hz}, 1 \mathrm{H}), 2.14-2.35$ (m, 4H), 1.82-1.93 (m, 2H), 1.72-1.79 (m, 2H), 1.61-1.69 (m, 1H), 1.48-1.59 (m, 3H), 1.01-1.07 (m, 21H), 0.89 (s, 3H), 0.79 (s, 3H); ${ }^{13} \mathrm{C}$ NMR (100 $\left.\mathrm{MHz}, \mathrm{CDCl}_{3}\right) \delta 185.60,175.79,138.94,138.81,137.27,135.48,135.38,134.78,129.38$, 129.04, 127.41, 117.98, 117.72, 117.18, 116.58, 116.18, 96.51, 83.45, 77.72, 77.20, 73.62, 72.81, 69.97, 69.65, 68.71, 60.40, 55.89, 47.44, 40.29, 40.11, 39.59, 39.07, 38.86, 37.80, 32.95, 23.34, 20.96, 20.93, 18.13, 12.06; IR (film) 3494, 3075, 2943, 2866, 1697, 1641, $1463,1365,1320,1182,1151,1097,921,882,807,738 \mathrm{~cm}^{-1} ;[\alpha]^{28}=+40.8(c=0.45$, 
$\mathrm{CH}_{2} \mathrm{Cl}_{2}$ ); $\mathrm{MS}$ (electrospray ionization) calculated for $\mathrm{C}_{49} \mathrm{H}_{79} \mathrm{NO}_{8} \mathrm{SSiNa}[\mathrm{M}+\mathrm{Na}]^{+}$: 892.52, found 892.60 .

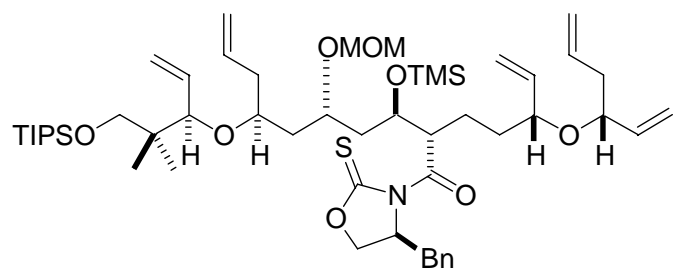

A $250 \mathrm{~mL}$ flask was charged with alcohol 22 (2.7 g, $3.10 \mathrm{mmol})$ and $31 \mathrm{~mL}$ of dichloromethane. After cooling the reaction to $0{ }^{\circ} \mathrm{C}$, triethylamine $(0.610 \mathrm{~mL}, 4.38 \mathrm{mmol})$, trimethylsilyl chloride $(0.470 \mathrm{~mL}, 3.70 \mathrm{mmol})$ and dimethylaminopyridine $(0.038 \mathrm{~g}, 0.311$ mmol) were added to the reaction mixture. The reaction was stirred at $0{ }^{\circ} \mathrm{C}$ for 1.5 hours followed by quenching of the reaction by the addition of water. The product was extracted three times with dichloromethane, and the combined organic layers were dried over $\mathrm{Na}_{2} \mathrm{SO}_{4}$. Concentration in vacuo followed by purification by flash column chromatography (5\% to 10\% EtOAc/hexanes) provided $2.57 \mathrm{~g}$ (88\%) of the silyl ether: ${ }^{1} \mathrm{H}$ NMR (400 $\left.\mathrm{MHz}, \mathrm{CDCl}_{3}\right)$ $\delta$ 7.30-7.33 (m, 2H), 7.21-7.27 (m, 3H), 5.69-5.85 (m, 3H), 5.55-5.66 (m, 2H), 4.97-5.17 (m, 11H), 4.80-4.83 (m, 1H), 4.57 (q, $J=14.8,6.8 \mathrm{~Hz}, 2 \mathrm{H}), 4.25$ (dd, $J=9.2,1.6 \mathrm{~Hz}, 1 \mathrm{H}), 4.13-$ 4.17 (m, 1H), 4.06-4.10 (m, 1H), 3.73-3.81 (m, 2H), 3.59-3.62 (m, 2H), 3.41-3.49 (m, 3H), 3.29-3.34 (m, 4H), 2.71 (dd, $J=13.2,10.8 \mathrm{~Hz}, 1 \mathrm{H}), 2.10-2.35$ (m, 4H), 1.88 (ddd, $J=14.2$, 8.0, $4.0 \mathrm{~Hz}, 1 \mathrm{H}), 1.59-1.81(\mathrm{~m}, 1 \mathrm{H}), 1.42-1.52$ (m, 2H), 1.01-1.06 (m, 21H), 0.88 (s, 3H), 0.80 (s, 3H), 0.10 (s, 9H); ${ }^{13} \mathrm{C}$ NMR (100 MHz, $\left.\mathrm{CDCl}_{3}\right) \delta 185.28,175.61,139.02,138.86$, 137.16, 135.75, 135.50, 134.83, 129.45, 129.00, 127.35, 117.94, 117.30, 117.20, 116.56, 116.22, 95.48, 82.50, 77.73, 73.05, 72.48, 71.37, 69. 83, 69.62, 60.91, 55.78, 48.37, 41.21, 40.30, 39.98, 39.59, 39.20, 37.58, 32.97, 24.82, 21.02, 20.80, 18.48, 18.14, 12.03, 0.56; IR (film) 2944, 1698, 1363, 1322, 1250, 1184, 1096, 921, 882, $841 \mathrm{~cm}^{-1} ;[\alpha]^{24}{ }_{\mathrm{D}}=+47.4(c=$ 
0.34, $\mathrm{CH}_{2} \mathrm{Cl}_{2}$ ); $\mathrm{MS}$ (electrospray ionization) calculated for $\mathrm{C}_{52} \mathrm{H}_{87} \mathrm{NO}_{8} \mathrm{SSi}_{2} \mathrm{Na}[\mathrm{M}+\mathrm{Na}]^{+}$: 964.56, found 964.60.

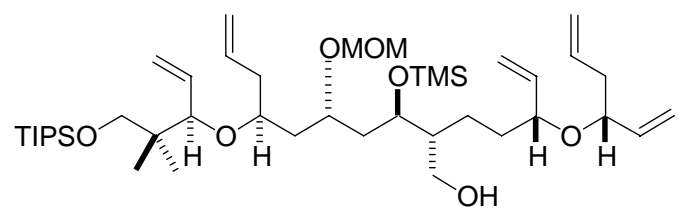

A $50 \mathrm{~mL}$ flask was charged with the acyl oxazolidinethione from the reaction above (248 $\mathrm{mg}, 0.263 \mathrm{mmol}$ ), $28 \mathrm{~mL}$ of $\mathrm{THF}$, and $7 \mathrm{~mL}$ of water. Sodium borohydride (15 $\mathrm{mg}, 0.396 \mathrm{mmol}$ ) was added, and the reaction mixture was stirred for 3 hours. The reaction was slowly quenched by the addition of saturated potassium/sodium tartrate solution, and the mixture was stirred vigorously overnight. The aqueous layer was extracted three times with ethyl acetate. The combined organic layers were dried over $\mathrm{Na}_{2} \mathrm{SO}_{4}$ and concentrated in vacuo. Purification by flash column chromatography (10\% EtOAc/hexanes) afforded $139 \mathrm{mg}(70 \%)$ of the alcohol: ${ }^{1} \mathrm{H}$ NMR (400 $\left.\mathrm{MHz}, \mathrm{CDCl}_{3}\right)$

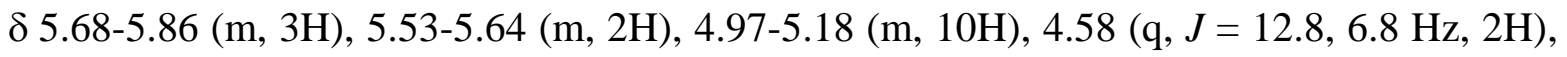
4.00-4.04 (m, 3H), 3.77 (q, $J=14.4,6.8 \mathrm{~Hz}, 1 \mathrm{H}), 3.64-3.72(\mathrm{~m}, 3 \mathrm{H}), 3.60$ (d, $J=8.4 \mathrm{~Hz}$, 1H), 3.46-3.50 (m, 1H), 3.43 (q, $J=16.0,9.2 \mathrm{~Hz}, 2 \mathrm{H}), 3.33$ (s, 3H), 3.06 (dd, $J=7.6,2.8$ Hz, 1H), 2.13-2.34 (m, 4H), 1.89 (ddd, $J=14.2,7.2,4.4 \mathrm{~Hz}, 1 \mathrm{H}), 1.79-1.80$ (m, 1H), $1.53-$ $1.61(\mathrm{~m}, 2 \mathrm{H}), 1.42-1.51(\mathrm{~m}, 2 \mathrm{H}), 1.14-1.28(\mathrm{~m}, 2 \mathrm{H}), 1.02-1.06(\mathrm{~m}, 23 \mathrm{H}), 0.88(\mathrm{~s}, 3 \mathrm{H}), 0.80$ (s, 3H), 0.14 (s, 9H); ${ }^{13} \mathrm{C}$ NMR (100 MHz, $\left.\mathrm{CDCl}_{3}\right) \delta 139.06,138.78,137.17,135.55$, 134.70, 117.90, 117.18, 117.10, 116.61, 116.37, 95.70, 82.80, 77.53, 73.37, 72.92, 69.60, 64.13, 55.70, 45.09, 40.27, 40.00, 39.58, 39.32, 38.08, 33.60, 23.47, 21.08, 20.73, 18.12, 12.03, 0.50; IR (film) 3476, 3076, 2944, 2867, 1642, 1464, 1252, 1039, 994, 921, 882, 841, $750,682 \mathrm{~cm}^{-1} ;[\alpha]^{25}{ }_{\mathrm{D}}=+14.0\left(c=1.38, \mathrm{CH}_{2} \mathrm{Cl}_{2}\right) ; \mathrm{MS}$ (electrospray ionization) calculated for $\mathrm{C}_{42} \mathrm{H}_{80} \mathrm{O}_{7} \mathrm{Si}_{2} \mathrm{Na}[\mathrm{M}+\mathrm{Na}]^{+}$: 775.53, found 775.60. 


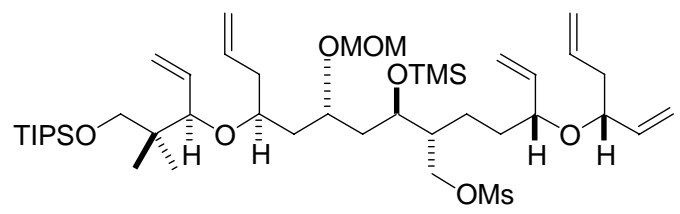

To a $50 \mathrm{~mL}$ flask was added the alcohol from the above $(62 \mathrm{mg}, 0.082 \mathrm{mmol})$ and $1.7 \mathrm{~mL}$ of dichloromethane. Upon cooling to $0{ }^{\circ} \mathrm{C}$, triethylamine $(0.057 \mathrm{~mL}, 0.409 \mathrm{mmol})$ and methanesulfonyl chloride $(0.032 \mathrm{~mL}, 0.413 \mathrm{mmol})$ were added to the reaction mixture. The reaction was stirred at $0{ }^{\circ} \mathrm{C}$ for 3 hours followed by quenching of the reaction by the addition of water. The product was extracted three times with dichloromethane. The combined organic layers were dried over $\mathrm{Na}_{2} \mathrm{SO}_{4}$ and concentrated in vacuo. The crude mesylate was filtered through a small plug of silica gel eluting with dichloromethane and concentrated in vacuo. The mesylate was used immediately in the following deoxygenation reaction: ${ }^{1} \mathrm{H}$ NMR $\left(400 \mathrm{MHz}, \mathrm{CDCl}_{3}\right) \delta$ 5.67-5.85 (m, 3H), 5.54-5.64 (m, 2H), 5.10-5.18 (m, 5H), 5.03-5.08 (m, 2H), 4.97-5.01 (m, 3H), 4.57 (q, $J=12.4,6.8 \mathrm{~Hz}, 2 \mathrm{H}), 4.29$ (dd, $J=$ 9.6, $5.2 \mathrm{~Hz}, 1 \mathrm{H}$ ), 4.09 (dd, $J=9.6,6.8 \mathrm{~Hz}, 1 \mathrm{H}), 3.97$ (dt, $J=9.2,3.2 \mathrm{~Hz}, 1 \mathrm{H}), 3.77$ (q, $J=$ 14.4, $6.8 \mathrm{~Hz}, 1 \mathrm{H}$ ), 3.70 (q, $J=13.6,6.8 \mathrm{~Hz}, 1 \mathrm{H}$ ), 3.65 (s, 1H), 3.60 (app d, $J=8.4 \mathrm{~Hz}, 2 \mathrm{H}$ ), 3.40-3.48 (m, 3H), 3.23 (s, 3H), 2.95 (s, 3H), 2.11-2.33 (m, 4H), 1.80-1.88 (m, 2H), 1.541.62 (m, 2H), 1.33-1.52 (m, 4H), 1.01-1.08 (m, 21 H), 0.88 (s, 3H), 0.79 (s, 3H), 0.10 (s, $9 \mathrm{H})$.

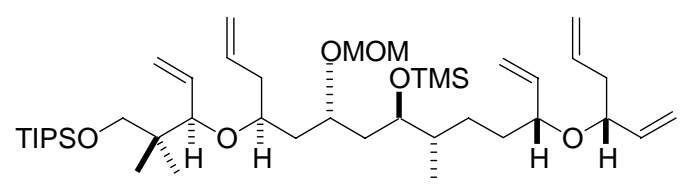

Pentaene 5. A $3 \mathrm{~mL}$ vial was charged with the mesylate $(684 \mathrm{mg}, 0.0823 \mathrm{mmol})$ and 0.83 $\mathrm{mL}$ of THF. Lithium triethylborohydride $(1.0 \mathrm{M}$ in THF, $0.830 \mathrm{~mL}, 0.830 \mathrm{mmol})$ was added to the reaction mixture dropwise. After stirring at ambient temperature for 3 hours, 
the reaction was carefully quenched with water. The aqueous layer was extracted three times with dichloromethane, and the combined organic layers were dried over $\mathrm{Na}_{2} \mathrm{SO}_{4}$. Concentration in vacuo followed by purification by flash column chromatography ( $5 \%$ to 10\% EtOAc/hexanes) provided $51.1 \mathrm{mg}$ (84\% over two steps) of pentaene 5: ${ }^{1} \mathrm{H}$ NMR (400 MHz, $\left.\mathrm{CDCl}_{3}\right) \delta$ 5.68-5.87 (m, 3H), 5.53-5.65 (m, 2H), 4.96-5.18 (m, 10H), 4.58 (q, $J=18.8$, $6.8 \mathrm{~Hz}, 2 \mathrm{H}), 3.78(\mathrm{q}, J=14.4,6.8 \mathrm{~Hz}, 1 \mathrm{H}), 3.71-3.76(\mathrm{~m}, 1 \mathrm{H}), 3.60(\mathrm{~d}, J=8.4 \mathrm{~Hz}, 1 \mathrm{H})$, 3.44-3.50 (m, 1H), 3.43 (q, J = 18.4, 9.2 Hz, 2H), 3.32 (s, 3H), 2.26-2.35 (m, 2H), 2.10-2.24 (m, 2H), 1.85 (ddd, $J=14.0,7.6,4.0 \mathrm{~Hz}, 1 \mathrm{H}), 1.40-1.56$ (m, 6H), 1.28-1.38 (m, 1H), 1.00$1.08(\mathrm{~m}, 24 \mathrm{H}), 0.87$ (s, 3H), $0.80(\mathrm{~d}, J=6.8 \mathrm{~Hz}, 3 \mathrm{H}), 0.80$ (s, 3H), $0.08(\mathrm{~s}, 9 \mathrm{H}) ;{ }^{13} \mathrm{C}$ NMR $\left(100 \mathrm{MHz}, \mathrm{CDCl}_{3}\right) \delta 139.30,138.90,137.23,135.80,134.82,117.90,117.02,116.57$, 116.19, 96.06, 82.56, 77.92, 77.22, 73.63, 72.87, 72.46, 69.60, 55.70, 40.31, 39.95, 39.83, 39.30, 38.98, 38.26, 33.69, 28.45, 21.16, 20.64, 18.14, 13.40, 12.03, 0.69; IR (film) 3076, 2944, 2867, 1642, 1464, 1383, 1250, 1096, 1068, 1040, 994, 922, 882, 840, 749, $681 \mathrm{~cm}^{-1}$; $[\alpha]_{\mathrm{D}}^{25}=+10.1\left(c=0.14, \mathrm{CH}_{2} \mathrm{Cl}_{2}\right) ; \quad$ MS (electrospray ionization) calculated for $\mathrm{C}_{42} \mathrm{H}_{80} \mathrm{O}_{6} \mathrm{Si}_{2} \mathrm{Na}[\mathrm{M}+\mathrm{Na}]^{+}:$759.54, found 759.60 .

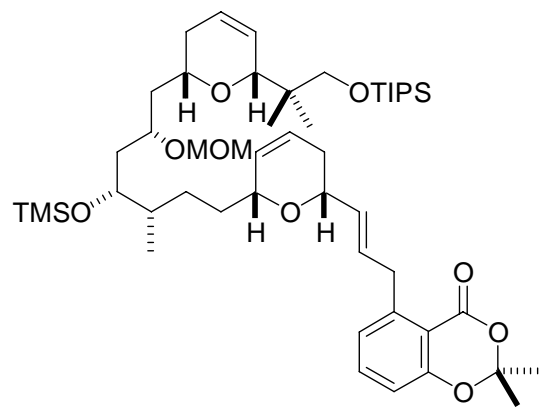

Triene 23. A $3 \mathrm{~mL}$ vial equipped with an air condenser was charged with pentaene 5 (55 $\mathrm{mg}, 0.075 \mathrm{mmol}$ ), dioxinone 4 (163 mg, $0.747 \mathrm{mmol}$ ), and $1.5 \mathrm{~mL}$ of dichloromethane. The solution was degassed for 30 minutes by bubbling dry argon through the solution, and 1,3- 
bis-(2,4,6-trimethylphenyl)-2-(imidazolidinylidene)

(dichlorophenylmethylene)

(tricyclohexylphosphine)-ruthenium (61 mg, $0.074 \mathrm{mmol}, 10 \mathrm{~mol} \%$ ) was added. The reaction was brought to reflux for 2.5 hours. After cooling to room temperature, the solution was diluted with hexanes and stirred overnight. The dioxinone dimer precipitate was filtered and washed with hexanes. The mother liquor was concentrated in vacuo, and purification by flash column chromatography (5\% to $10 \%$ EtOAc/hexanes) provided 57.1 mg (88\%) of triene 23: ${ }^{1} \mathrm{H}$ NMR $\left(400 \mathrm{MHz}, \mathrm{CDCl}_{3}\right) \delta 7.39(\mathrm{t}, J=8.0 \mathrm{~Hz}, 1 \mathrm{H}), 6.94(\mathrm{~d}, J=$ 7.6 Hz, 1H), 6.80 (d, $J=7.6 \mathrm{~Hz}, 1 \mathrm{H}), 5.89$ (ddt, $J=15.6,6.8,1.2 \mathrm{~Hz}, 1 \mathrm{H}), 5.72-5.81$ (m, 3H), 5.52-5.63 (m, 2H), 4.62 (q, $J=10.8,6.8 \mathrm{~Hz}, 2 \mathrm{H}), 4.08$ (bs, 1H), 3.99-4.03 (m, 1H), 3.95 (bs, $1 \mathrm{H}$ ), 3.85 (d, $J=6.4 \mathrm{~Hz}, 2 \mathrm{H}), 3.75-3.77$ (m, 2H), 3.50-3.68 (m, 1H), 3.48 (s, 2H), 3.33 (s, 3H), 2.01-2.09 (m, 1H), 1.79-1.95 (m, 4H), 1.67 (s, 6H), 1.38-1.63 (m, 8H), 1.00$1.11(\mathrm{~m}, 21 \mathrm{H}), 0.89$ (s, 3H), 0.82 (s, 6H), 0.07 (s, 9H); ${ }^{13} \mathrm{C}$ NMR (100 MHz, $\left.\mathrm{CDCl}_{3}\right)$ $\delta$ 160.22, 157.07, 145.32, 135.29, 132.48, 130.06, 129.56, 127.67, 125.54, 125.09, 124.37, 115.53, 111.98, 105.12, 96.12, 78.83, 77.20, 75.04, 74.28, 73.67, 72.98, 70.39, 69.61, 55.59, 42.16, 39.94, 39.50, 38.11, 36.80, 33.68, 31.41, 31.31, 28.12, 25.62, 20.78, 20.51, 18.05, 11.97, 0.66; IR (film) 2943, 2866, 1739, 1605, 1583, 1477, 1390, 1315, 1250, 1209, 1095, 1043, 919, 882, 840, 734, $682 \mathrm{~cm}^{-1} ;[\alpha]^{25}=+5.8\left(c=2.00, \mathrm{CH}_{2} \mathrm{Cl}_{2}\right) ; \quad$ MS (electrospray ionization) calculated for $\mathrm{C}_{49} \mathrm{H}_{82} \mathrm{O}_{9} \mathrm{Si}_{2} \mathrm{Na}[\mathrm{M}+\mathrm{Na}]^{+}$: 893.54, found 893.60 .

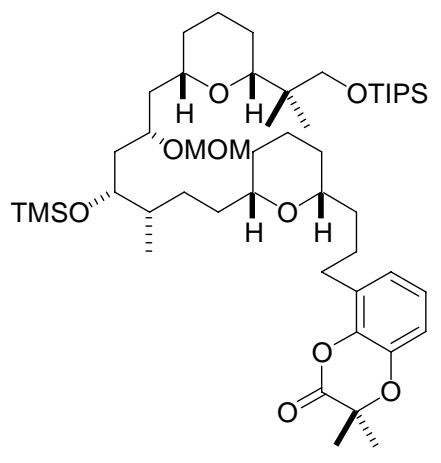


Saturated dioxinone 2. A $25 \mathrm{~mL}$ flask equipped with a balloon adapter was charged with triene 23 (21 mg, $0.024 \mathrm{mmol}$ ) and $3.0 \mathrm{~mL}$ of ethyl acetate. Rhodium on alumina (5 wt\%, 5 $\mathrm{mg}, 0.0024 \mathrm{mmol}$ ) was added to the reaction mixture. The reaction atmosphere was evacuated and filled with hydrogen (balloon). After stirring the mixture overnight, the hydrogen balloon was removed and the reaction was filtered through a small pad of silica gel washing with $15 \mathrm{~mL}$ of ethyl acetate. Concentration in vacuo followed by purification by flash column chromatography (5\% to 10\% EtOAc/hexanes) provided $19.8 \mathrm{mg}(94 \%)$ of saturated dioxinone 2: ${ }^{1} \mathrm{H}$ NMR (400 MHz, $\left.\mathrm{CDCl}_{3}\right) \delta 7.36(\mathrm{t}, J=7.8 \mathrm{~Hz}, 1 \mathrm{H}), 6.91$ (d, $J=$ $7.6 \mathrm{~Hz}, 1 \mathrm{H}), 6.77$ (dd, $J=8.2,1.0 \mathrm{~Hz}, 1 \mathrm{H}), 4.60$ (q, $J=9.0,2.6 \mathrm{~Hz}, 2 \mathrm{H}), 3.74-3.78(\mathrm{~m}, 2 \mathrm{H})$, $3.42(\mathrm{q}, J=19.2,9.2 \mathrm{~Hz}, 2 \mathrm{H}), 3.32$ (s, 3H), 3.16-3.30 (m, 2H), 3.12 (dd, $J=11.2,1.6 \mathrm{~Hz}$, 1H), 3.05-3.09 (m, 2H), 1.75-1.82 (m, 3H), 1.63-1.71 (m, 7H). 1.39-1.62 (m, 14H), 0.98$1.13(\mathrm{~m}, 21 \mathrm{H}), 0.89$ (s, 3H), 0.81 (d, $J=6.8 \mathrm{~Hz}, 3 \mathrm{H}), 0.78$ (s, 3H), 0.06 (s, 9H); ${ }^{13} \mathrm{C}$ NMR $\left(100 \mathrm{MHz}, \mathrm{CDCl}_{3}\right) \delta 160.20,157.09,148.20,135.08,125.20,115.09,112.04,104.92,96.08$, 81.85, 78.16, 77.70, 77.20, 74.70, 73.66, 73.01, 69.76, 55.57, 42.76, 39.47, 39.36, 37.91, 36.42, 34.78, 34.22, 31.95, 31.67, 31.57, 28.75, 27.12, 25.68, 25.60, 25.17, 24.13, 23.74, 21.58, 18.07, 13.75, 11.99, 0.67; IR (film) 2939, 1741, 1606, 1582, 1476, 1388, 1262, 1210 , 1042, 920, $840 \mathrm{~cm}^{-1} ;[\alpha]^{27}=+5.38\left(c=1.50, \mathrm{CH}_{2} \mathrm{Cl}_{2}\right) ; \quad$ MS (electrospray ionization) calculated for $\mathrm{C}_{49} \mathrm{H}_{88} \mathrm{O}_{9} \mathrm{Si}_{2} \mathrm{Na}[\mathrm{M}+\mathrm{Na}]^{+}$: 899.59, found 899.40.

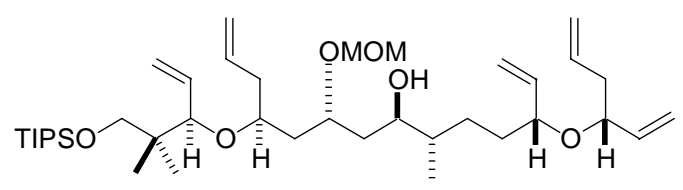

To a $20 \mathrm{~mL}$ vial was added silyl ether 5 (58 $\mathrm{mg}, 0.079 \mathrm{mmol}$ ) and $2.0 \mathrm{~mL}$ of methanol. The solution was cooled to $0{ }^{\circ} \mathrm{C}$ and pyridinium para-toluenesulfonate (2.0 mg, $0.00796 \mathrm{mmol}$ ) was added. After stirring the reaction mixture 30 minutes at $0{ }^{\circ} \mathrm{C}$, the 
reaction was quenched with water and the solution was diluted with dichloromethane. The product was extracted three with dichloromethane and the combined organic layers were dried over $\mathrm{Na}_{2} \mathrm{SO}_{4}$. Concentration in vacuo followed by purification by flash column chromatography (17.5\% EtOAc/hexanes) provided $51.8 \mathrm{mg}$ (99\%) of the hydroxy pentaene: ${ }^{1} \mathrm{H}$ NMR (400 MHz, CDCl $)$ ઈ 5.67-5.83 (m, 3H), 5.54-5.65 (m, 2H), 4.96-5.18 (m, 10H), 4.59 (q, $J=11.6,6.8 \mathrm{~Hz}, 2 \mathrm{H}), 3.86-3.92(\mathrm{~m}, 1 \mathrm{H}), 3.77(\mathrm{q}, J=14.0,6.4 \mathrm{~Hz}, 1 \mathrm{H}), 3.69(\mathrm{q}, J=$ 14.0, $6.4 \mathrm{~Hz}, 1 \mathrm{H}), 3.63-3.67$ (m, 1H), 3.61 (d, $J=8.8 \mathrm{~Hz}, 1 \mathrm{H}), 3.39-3.46$ (m, 3H), 3.35 (s, 3H), 2.96 (d, $J=3.6 \mathrm{~Hz}, 1 \mathrm{H}), 2.14-2.34$ (m, 4H), 1.87 (ddd, $J=12.4,7.2,5.2 \mathrm{~Hz}, 1 \mathrm{H}), 1.59$ (ddd, $J=14.4,11.2,3.6 \mathrm{~Hz}, 1 \mathrm{H}), 1.46-1.52$ (m, 6H), 1.00-1.08 (m, 22H), 0.89 (s, 3H), 0.84 (d, $J=6.8 \mathrm{~Hz}, 3 \mathrm{H}), 0.79$ (s, 3H); ${ }^{13} \mathrm{C}$ NMR $\left(100 \mathrm{MHz}, \mathrm{CDCl}_{3}\right) \delta$ 139.26, 138.87, 137.19, 135.36, 134.83, 117.96, 116.93, 116.90, 116.52, 116.50, 96.31, 83.09, 78.11, 77.18, 73.79, 72.77, 71.33, 69.62, 55.92, 40.30, 40.02, 39.53, 38.84, 38.76, 37.68, 33.20, 27.91, 20.92, 20.74, 18.35, 18.09, 12.00; IR (film) 3508, 3076, 2943, 2360, 1642, 1464, 1422, 1383, 1317, 1244, 1097, 921, 882, 810, 735, $681 \mathrm{~cm}^{-1} ;[\alpha]_{\mathrm{D}}^{26}=+19.3\left(c=0.22, \mathrm{CH}_{2} \mathrm{Cl}_{2}\right) ; \mathrm{MS}$ (electrospray ionization) calculated for $\mathrm{C}_{39} \mathrm{H}_{72} \mathrm{O}_{6} \mathrm{SiNa}[\mathrm{M}+\mathrm{Na}]^{+}$: 687.50, found 687.50.

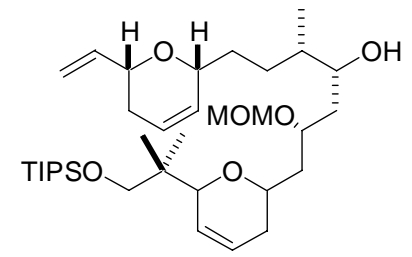

Alcohol 3. To a $100 \mathrm{~mL}$ flask equipped with a condenser was added the hydroxy pentaene from above (28 mg, $0.042 \mathrm{mmol}$ ) and $42 \mathrm{~mL}$ of dichloromethane. The solution was degassed for 30 minutes by bubbling dry argon through the solution and benzylidenebis(tricyclohexylphosphine)dichlororuthenium (3.5 mg, $0.004 \mathrm{mmol}, 10 \mathrm{~mol} \%$ ) was added. The reaction was brought to reflux for 1.5 hours and then cooled to room temperature. The 
solution was stirred vigorously open to air overnight and then concentrated in vacuo. Purification by flash column chromatography (17.5 \% EtOAc/Hexanes) provided $22.5 \mathrm{mg}$ (88\%) of alcohol 3: ${ }^{1} \mathrm{H}$ NMR (400 MHz, $\left.\mathrm{CDCl}_{3}\right) \delta 5.89$ (ddd, $J=17.2,10.4,5.2 \mathrm{~Hz}, 1 \mathrm{H}$ ), 5.76-5.82 (m, 2H), 5.73 (dd, $J=10.6,1.0 \mathrm{~Hz}, 1 \mathrm{H}), 5.64$ (dt, $J=10.4,1.2 \mathrm{~Hz}, 1 \mathrm{H}), 5.25$ (dt, $J=17.6,1.6 \mathrm{~Hz}, 1 \mathrm{H}), 5.10(\mathrm{dt}, J=10.7,1.4 \mathrm{~Hz}, 1 \mathrm{H}), 4.63(\mathrm{q}, J=16.4,6.4 \mathrm{~Hz}, 2 \mathrm{H}), 4.14$ (bs, 1H), 4.02-4.06 (m, 2H), 3.96 (d, $J=1.2 \mathrm{~Hz}, 1 \mathrm{H}), 3.68-3.72$ (m, 1H), 3.49-3.58 (m, 2H), 3.36 (s, 3H), 3.04 (d, $J=3.2$ Hz, 1H), 2.04-2.13 (m, 1H), 1.98-2.01 (m, 1H), 1.86-1.97 (m, 3H), 1.68-1.71 (m, 1H), 1.47-1.66 (m, 5H), 1.18-1.30 (m, 3H), 0.99-1.11 (m, 21H), 0.68$0.88(\mathrm{~m}, 9 \mathrm{H}) ;{ }^{13} \mathrm{C}$ NMR $\left(100 \mathrm{MHz}, \mathrm{CDCl}_{3}\right) \delta 138.91,130.24,127.60,125.48,124.21$, 114.84, 95.98, 78.67, 75.10, 74.43, 73.62, 71.46, 70.48, 69.61, 55.81, 40.60, 39.90, 38.87, 36.77, 33.02, 31.57, 30.96, 27.59, 22.64, 20.78, 20.23, 18.07; IR (film) 3521, 2942, 2866, 1463, 1391, 1097, 1035, 920, 882, $806 \mathrm{~cm}^{-1} ; \quad[\alpha]_{\mathrm{D}}^{27}=+9.3\left(c=0.94, \mathrm{CH}_{2} \mathrm{Cl}_{2}\right) ; \quad \mathrm{MS}$ (electrospray ionization) calculated for $\mathrm{C}_{35} \mathrm{H}_{64} \mathrm{O}_{6} \mathrm{SiNa}[\mathrm{M}+\mathrm{Na}]^{+}$: 631.44, found 631.40.

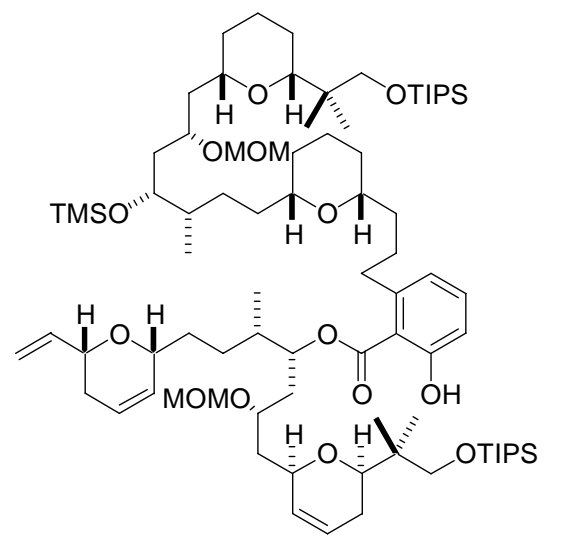

A $20 \mathrm{~mL}$ vial was charged with saturated dioxinone 2 (19 mg, $0.022 \mathrm{mmol}$ ), alcohol 3 (12 mg, $0.020 \mathrm{mmol}$ ), and $2.0 \mathrm{~mL}$ of THF. The solution was cooled to $0{ }^{\circ} \mathrm{C}$ and sodium bis(trimethylsilyl)amide (0.68 $\mathrm{M}$ in toluene/THF, $0.100 \mathrm{~mL}, 0.068 \mathrm{mmol})$ was added dropwise. After stirring at $0{ }^{\circ} \mathrm{C}$ for 1.25 hours, the reaction was quenched by the addition of 
water. The product was extracted three times with dichloromethane. The combined organic layer were dried over $\mathrm{Na}_{2} \mathrm{SO}_{4}$ and concentrated in vacuo. Purification by flash column chromatography (10\% EtOAc/Hexanes) provided $26.3 \mathrm{mg}$ (84\%) of the ester: ${ }^{1} \mathrm{H}$ NMR (400 MHz, $\left.\mathrm{CDCl}_{3}\right) \delta 11.12(\mathrm{~s}, 1 \mathrm{H}), 7.25(\mathrm{t}, J=8.0 \mathrm{~Hz}, 1 \mathrm{H}), 6.79$ (dd, $\left.J=8.4,0.8 \mathrm{~Hz}, 1 \mathrm{H}\right)$, 6.70 (d, $J=7.2 \mathrm{~Hz}, 1 \mathrm{H}$ ), 5.87 (ddd, $J=16.0,10.8,5.6 \mathrm{~Hz}, 1 \mathrm{H}$ ), 5.72-5.80 (m, 3H), 5.60 (dt, $J=10.4,1.2 \mathrm{~Hz}, 1 \mathrm{H}), 5.45$ (dt, $J=8.0,4.8 \mathrm{~Hz}, 1 \mathrm{H}), 5.22$ (dt, $J=17.6,1.6 \mathrm{~Hz}, 1 \mathrm{H}), 5.07$ (dt, $J=10.8,1.6 \mathrm{~Hz}, 1 \mathrm{H}), 4.60$ (d, $J=1.6 \mathrm{~Hz}, 2 \mathrm{H}), 4.58$ (q, $J=29.2,6.8 \mathrm{~Hz}, 2 \mathrm{H}), 4.14$ (bs, $1 \mathrm{H})$, 4.00-4.05 (m, 1H), 3.92 (bs, 1H), 3.75-3.78 (m, 3H), 3.59-3.65 (m, 1H), 3.37-3.49 (m, 4H), 3.29-3.34 (m, 7H), 3.13-3.22 (m, 2H), 3.12 (dd, $J=11.2,1.6 \mathrm{~Hz}, 1 \mathrm{H}), 2.89$ (t, $J=7.2 \mathrm{~Hz}$, 2H), 1.94-2.09 (m, 2H), 1.75-1.93 (m, 9H), 1.63-1.73 (m, 2H), 1.39-1.57 (m, 20H), 1.101.32 (m, 6H), 0.99-1.08 (m, 44H), 0.96 (d, $J=6.8 \mathrm{~Hz}, 3 \mathrm{H}), 0.90$ (s, 3H), 0.82 (d, $J=6.8 \mathrm{~Hz}$, 3H), 0.78 (s, 6H), 0.07 (s, 9H); ${ }^{13} \mathrm{C}$ NMR (100 MHz, $\left.\mathrm{CDCl}_{3}\right) \delta 170.96,162.30,145.34$, 138.88, 133.74, 130.14, 127.67, 125.40, 124.46, 122.12, 115.66, 114.67, 112.64, 96.26, 96.10, 81.87, 78.97, 78.18, 77.73, 77.20, 74.73, 74.64, 74.29, 73.65, 73.01, 72.45, 69.96, $69.78,69.60,60.37,55.85,55.55,42.79,41.23,39.93,39.48,39.40,37.98,36.78,36.69$, 36.06, 35.48, 34.75, 33.11, 31.96, 31.78, 31.71, 31.63, 31.42, 30.95, 28.69, 28.11, 28.06, 25.19, 24.14, 23.72, 21.59, 20.92, 20.62, 20.38, 18.06, 14.97, 13.79, 12.01; IR (film) 2941, 2866, 1655, 1606, 1450, 1383, 1250, 1212, 1096, 1040, 919, 882, 840, 815, $612 \mathrm{~cm}^{-1}$; $[\alpha]_{\mathrm{D}}^{27}=+4.5\left(c=1.67, \mathrm{CH}_{2} \mathrm{Cl}_{2}\right) ; \quad$ MS (electrospray ionization) calculated for $\mathrm{C}_{81} \mathrm{H}_{146} \mathrm{O}_{14} \mathrm{Si}_{3} \mathrm{Na}[\mathrm{M}+\mathrm{Na}]^{+}:$1449.99, found 1450.00 . 


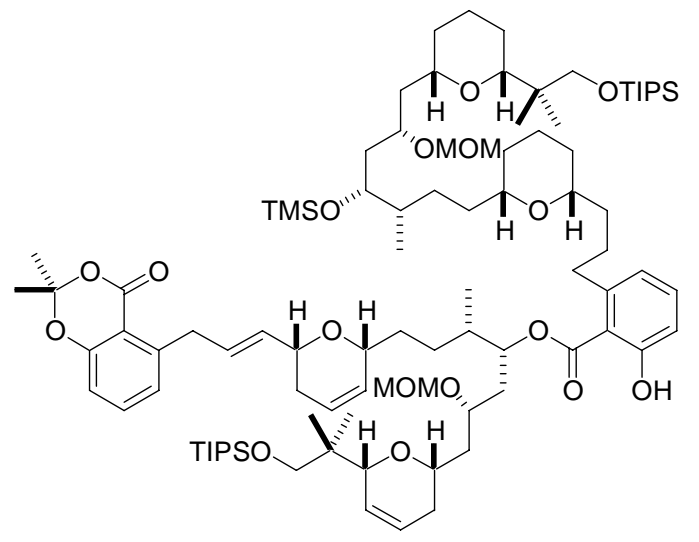

Triene 24. A $3 \mathrm{~mL}$ vial equipped with an air condenser was charged with the ester from above (22 $\mathrm{mg}, 0.015 \mathrm{mmol}$ ), dioxinone 4 (34 mg, $0.16 \mathrm{mmol}$ ), and $0.34 \mathrm{~mL}$ of dichloromethane. The solution was degassed for 30 minutes by bubbling dry argon through the solution and 1,3-bis-(2,4,6-trimethylphenyl)-2-(imidazolidinylidene)(dichlorophenylmethylene)-(tricyclohexylphosphine)-ruthenium (12 mg, $0.015 \mathrm{mmol}, 10$ mol\%) was added. The reaction was brought to reflux for 2.5 hours. After cooling to room temperature, the solution was diluted with hexanes and stirred overnight. The dioxinone dimer precipitate was filtered and washed with hexanes. The mother liquor was concentrated in vacuo, and purification by flash column chromatography (5\% to $10 \%$ EtOAc/hexanes) provided $16.5 \mathrm{mg}$ (66\%) of triene 24: ${ }^{1} \mathrm{H}$ NMR (400 MHz, $\left.\mathrm{CDCl}_{3}\right) \delta 11.15$ (s, 1H), 7.39 (t, $J=8.0 \mathrm{~Hz}, 1 \mathrm{H}$ ), 7.24 (t, $J=6.0 \mathrm{~Hz}, 1 \mathrm{H}$ ), 6.94 (d, $J=6.8 \mathrm{~Hz}, 1 \mathrm{H}$ ), 6.79 (ddd, $J=8.0,6.0,0.8 \mathrm{~Hz}, 1 \mathrm{H}), 6.70(\mathrm{~d}, J=7.6 \mathrm{~Hz}, 1 \mathrm{H}), 5.87$ (ddd, $J=14.8,6.8,6.0 \mathrm{~Hz}, 1 \mathrm{H})$, 5.72-5.80 (m, 3H), 5.51-5.62 (m, 2H), 5.44 (dt, $J=7.6,4.4 \mathrm{~Hz}, 1 \mathrm{H}), 4.58-4.62$ (m, 3H), 4.53 (d, $J=6.8 \mathrm{~Hz}, 1 \mathrm{H}$ ), 4.12 (bs, 1H), 3.99-4.02 (m, 1H), 3.92 (bs, 1H), 3.84 (d, $J=6.4 \mathrm{~Hz}, 2 \mathrm{H}$ ), 3.72-3.77 (m, 3H), 3.59-3.63 (m, 1H), 3.39-3.48 (m, 4H), 3.29-3.34 (m, 7H), 3.15-3.22 (m, 2H), 3.12 (dd, $J=11.2,1.2 \mathrm{~Hz}, 1 \mathrm{H}$ ), 2.88 (t, $J=7.6 \mathrm{~Hz}, 2 \mathrm{H}), 2.00-2.07$ (m, 1H), 1.75-1.94 (m, 9H), 1.66-1.72 (m, 9H), 1.37-1.64 (m, 20H), 1.10-1.25 (m, 6), 0.98-1.07 (m, 42H), 0.94 
(d, $J=6.8 \mathrm{~Hz}, 3 \mathrm{H}), 0.90$ (s, 3H), 0.84 (s, 3H), 0.82 (d, $J=6.8 \mathrm{~Hz}, 3 \mathrm{H}), 0.78$ (d, $J=4.0 \mathrm{~Hz}$, 6H), 0.07 (s, 9H); ${ }^{13} \mathrm{C}$ NMR (100 MHz, $\mathrm{CDCl}_{3}$ ) $\delta$ 171.00, 162.34, 160.24, 157.12, 145.41, 145.35, 135.32, 133.79, 132.58, 129.96, 129.46, 127.70, 125.43, 125.08, 124.65, 122.15, 115.69, 115.56, 112.64, 112.03, 105.15, 96.29, 96.13, 81.92, 79.01, 78.22, 77.74, 77.23, 74.76, 74.67, 74.22, 73.68, 73.05, 72.46, 70.00, 69.80, 69.62, 55.89, 55.59, 42.83, 41.31, 39.97, 39.51, 39.44, 38.01, 36.82, 36.72, 36.08, 35.46, 34.78, 33.12, 32.00, 31.81, 31.66, 31.45, 31.36, 28.72, 28.12, 28.05, 25.67. 25.22, 24.17, 23.75, 21.62, 20.98, 20.65, 20.41, 18.10, 14.89, 13.82, 12.04, 0.71; IR (film) 2941, 2865, 1740, 1654, 1605, 1583, 1449, 1389, $1313,1250,1212,1095,1042,919,882,840 \mathrm{~cm}^{-1} ;[\alpha]^{27}=-0.27\left(c=0.74, \mathrm{CH}_{2} \mathrm{Cl}_{2}\right) ; \mathrm{MS}$ (electrospray ionization) calculated for $\mathrm{C}_{92} \mathrm{H}_{156} \mathrm{O}_{17} \mathrm{Si}_{3} \mathrm{Na}[\mathrm{M}+\mathrm{Na}]^{+}$: 1640.06, found 1641.2.

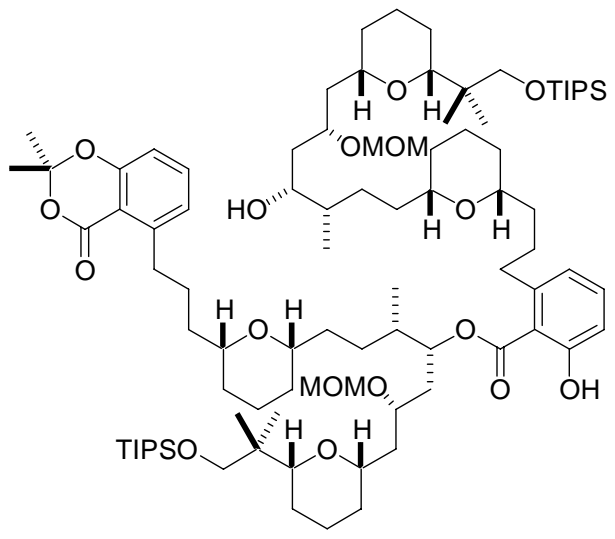

A $25 \mathrm{~mL}$ flask equipped with a balloon adapter was charged with triene 24 (33 mg, $0.020 \mathrm{mmol}$ ) and $6.0 \mathrm{~mL}$ of ethyl acetate. Rhodium on alumina (5 wt\%, $4 \mathrm{mg}, 0.0019$ mmol) was added to the reaction mixture. The reaction atmosphere was evacuated and filled with hydrogen. After stirring the mixture overnight, the hydrogen balloon was removed and the reaction was filtered through a small pad of silica gel washing with $30 \mathrm{~mL}$ of ethyl acetate. Concentration in vacuo followed by purification by flash column chromatography (10\% EtOAc/hexanes) provided $27.5 \mathrm{mg}(83 \%)$ of the saturated dioxinone: ${ }^{1} \mathrm{H}$ NMR (500 
$\left.\mathrm{MHz}, \mathrm{CDCl}_{3}\right) \delta 11.08(\mathrm{~s}, 1 \mathrm{H}), 7.36(\mathrm{t}, J=8.0 \mathrm{~Hz}, 1 \mathrm{H}), 7.23(\mathrm{t}, J=8.0 \mathrm{~Hz}, 1 \mathrm{H}), 6.90(\mathrm{~d}, J=$ $7.5 \mathrm{~Hz}, 1 \mathrm{H}), 6.77$ (t, $J=8.0 \mathrm{~Hz}, 2 \mathrm{H}), 6.69$ (d, $J=7.5 \mathrm{~Hz}, 1 \mathrm{H}), 5.41-5.48$ (m, 1H), 4.60 (q, $J$ = 1.0, $6.5 \mathrm{~Hz}, 2 \mathrm{H}), 4.55$ (q, $J=36.0,6.5 \mathrm{~Hz}, 2 \mathrm{H}), 3.75-3.77$ (m, 2H), 3.70 (bs, 1H), 3.44 (d, $J=9.0 \mathrm{~Hz}, 1 \mathrm{H}), 3.41$ (t, $J=9.5 \mathrm{~Hz}, 2 \mathrm{H}), 3.33$ (app t, $J=9.5 \mathrm{~Hz}, 2 \mathrm{H}), 3.32$ (s, 3H), 3.30 (s, 3H), 3.16-3.26 (m, 4H), 3.11 (t, $J=12.0 \mathrm{~Hz}, 2 \mathrm{H}), 3.06$ (t, $J=8.0 \mathrm{~Hz}, 2 \mathrm{H}), 2.88$ (bs, 2H), 1.86-1.88 (m, 1H), 1.76-1.80 (m, 7H), 1.69-1.73 (m, 2H), 1.67 (s, 6H), 1.60-1.63 (m, 4H), 1.36-1.56 (m, 27H), 1.16-1.23 (m, 2H), 1.05-1.15 (m, 8H), 0.98-1.04 (m, 42H), 0.93 (d, $J=$ $6.5 \mathrm{~Hz}, 3 \mathrm{H}), 0.90$ (s, 3H), 0.81 (d, $J=9.0 \mathrm{~Hz}, 3 \mathrm{H}), 0.80$ (s, 6H), 0.72 (s, 3H), 0.05 (s, 9H); ${ }^{13} \mathrm{C}$ NMR $\left(125 \mathrm{MHz}, \mathrm{CDCl}_{3}\right) \delta 170.84,162.07,160.19,157.07,148.16,145.23,135.08$, 133.65, 125.17, 122.07, 115.59, 115.09, 112.81, 112.03, 104.91, 96.10, 96.02, 81.90, 81.86, 78.18, 77.75, 77.70, 77.65, 77.20, 76.70, 74.70, 74,19, 73.65, 72.98, 72.31, 69.75, 55.83, 55.55, 42.77, 41.82, 39.46, 39.41, 39.39, 37.92, 36.68, 36.37, 35.95, 35.44, 34.74, 34.17, $32.17,31.95,31.75,31.61,31.56,31.41,38.68,38.64,28.00,27.06,25.70,25.63,25.56$, 25.16, 25.09, 24.13, 24.04, 23.69, 21.62, 21.58, 20.60, 20.39, 18.07, 14.79, 13.75, 11.95; IR (film) 2938, 2865, 1741, 1653, 1606, 1450, 1378, 1312, 1250, 1211, 1095, 1042, 920, 882, $812 \mathrm{~cm}^{-1} ;[\alpha]_{\mathrm{D}}^{27}=+6.82\left(c=0.60, \mathrm{CH}_{2} \mathrm{Cl}_{2}\right) ;$ MS (electrospray ionization) calculated for $\mathrm{C}_{92} \mathrm{H}_{162} \mathrm{O}_{17} \mathrm{Si}_{3} \mathrm{Na}[\mathrm{M}+\mathrm{Na}]^{+}:$1646.10, found 1646.10.

To a $20 \mathrm{~mL}$ vial was added the silyl ether (27 mg, $0.017 \mathrm{mmol})$ and $2.3 \mathrm{~mL}$ of methanol. Pyridinium para-toluenesulfonate $(0.4 \mathrm{mg}, 0.0016 \mathrm{mmol})$ was added and the reaction mixture was stirred 30 minutes at ambient temperature. The reaction was quenched with water and the solution was diluted with dichloromethane. The product was extracted three times with dichloromethane and the combined organic layers were dried over $\mathrm{Na}_{2} \mathrm{SO}_{4}$. Concentration in vacuo followed by purification by flash column chromatography $(17.5 \%$ 
EtOAc/hexanes) provided $22.8 \mathrm{mg}$ (88\%) of the hydroxy dioxinone: ${ }^{1} \mathrm{H}$ NMR (500 MHz, $\left.\mathrm{CDCl}_{3}\right) \delta 11.17(\mathrm{~s}, 1 \mathrm{H}), 7.36(\mathrm{t}, J=8.0 \mathrm{~Hz}, 1 \mathrm{H}), 7.23(\mathrm{t}, J=8.0 \mathrm{~Hz}, 1 \mathrm{H}), 6.90(\mathrm{~d}, J=7.5$ Hz, 1H), 6.77 (t, $J=8.0 \mathrm{~Hz}, 2 \mathrm{H}), 6.69$ (d, $J=7.5 \mathrm{~Hz}, 1 \mathrm{H}), 5.41-5.43(\mathrm{~m}, 1 \mathrm{H}), 4.61$ (q, $J=$ 19.0, $6.5 \mathrm{~Hz}, 2 \mathrm{H}), 4.55$ (q, $J=36.0,10.0 \mathrm{~Hz}, 2 \mathrm{H}), 4.00-4.01(\mathrm{~m}, 1 \mathrm{H}), 3.66-3.70(\mathrm{~m}, 2 \mathrm{H})$, 3.43 (s, 2H), 3.42 (d, $J=12.0 \mathrm{~Hz}, 1 \mathrm{H}), 3.35$ (s, 3H), 3.30 (s, 3H), 3.18-3.26 (m, 4H), 3.043.12 (m, 5H), 2.85-2.90 (m, 2H), 1.73-1.88 (m, 8H), 1.69-1.74 (m, 6H), 1.66 (s, 6H), 1.361.64 (m, 28H), 1.19-1.32 (m, 3H), 1.06-1.24 (m, 8H), 1.00-1.04 (m, 42H), 0.93 (d, $J=6.5$ Hz, 3H), 0.87 (s, 3H), 0.85 (d, J = 6.5 Hz, 3H), 0.80 (s, 3H), 0.79 (s, 3H), 0.18 (s, 3H); ${ }^{13} \mathrm{C}$ NMR (125 MHz, $\left.\mathrm{CDCl}_{3}\right) \delta 170.85,162.06,160.19,157.06,148.16,145.26,135.09,133.65$, 125.17, 122.09, 115.58, 115.09, 112.81, 112.03, 104.94, 104.91, 96.02, 95.78, 81.90, 81.87, 78.27, 77.76, 77.66, 74.65, 74.19, 73.56, 72.31, 71.48, 69.82, 69.74, 55.84, 55.76, 55.74, 41.83, 40.99, 39.50, 39.41, 38.80, 36.69, 36.66, 36.61, 36.37, 35.93, 35.45, 34.14, 33.98, 32.16, 32.03, 31.77, 31.61, 31.55, 31.38, 31.04, 28.63, 28.15, 28.00, 27.05, 25.69, 25.62, 25.56, 25.08, 25.02, 24.03, 23.70, 21.57, 20.81, 20.75, 20.38, 18.06, 15.06, 14.80, 11.95; IR (film) 3520, 2937, 2864, 1739, 1652, 1605, 1581, 1450, 1378, 1312, 1269, 1211, 1095, 1041, 921, 883, 809, 739, $681 \mathrm{~cm}^{-1} ;[\alpha]^{27}{ }_{\mathrm{D}}=+7.34\left(c=0.59, \mathrm{CH}_{2} \mathrm{Cl}_{2}\right)$; MS (electrospray ionization) calculated for $\mathrm{C}_{89} \mathrm{H}_{154} \mathrm{O}_{17} \mathrm{Si}_{3} \mathrm{Na}[\mathrm{M}+\mathrm{Na}+1]^{+}$: 1574.08, found 1575.10.

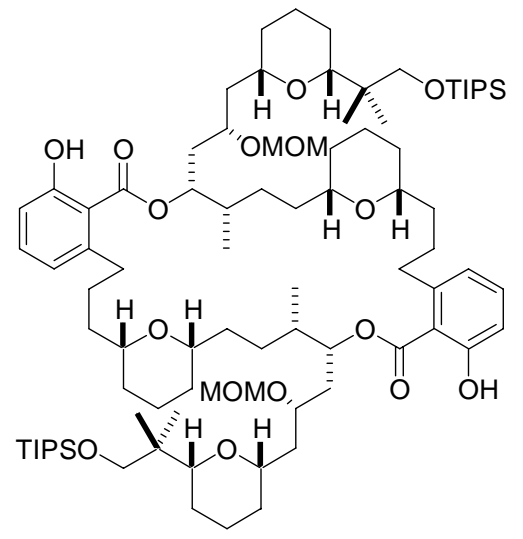


Macrodiolide 25. A $3 \mathrm{~mL}$ vial was charged with the alcohol from above $(6.7 \mathrm{mg}, 0.0043$ mmol) and $0.60 \mathrm{~mL}$ of THF. The solution was cooled to $-78{ }^{\circ} \mathrm{C}$ and sodium bis(trimethylsilyl)amide $(0.70 \mathrm{M}$ in toluene/THF, $0.062 \mathrm{~mL}, 0.0434 \mathrm{mmol})$ was added dropwise. After stirring at $-78{ }^{\circ} \mathrm{C}$ for 15 minutes, the reaction was slowly warmed to room temperature. The reaction was quenched with water and the product was extracted three times with dichloromethane. The combined organic layers were dried over $\mathrm{Na}_{2} \mathrm{SO}_{4}$ and concentrated in vacuo. Purification by flash column chromatography $(10 \%$ to $17.5 \%$ EtOAc/Hexanes) provided $3.0 \mathrm{mg}$ (47\%) of macrodiolide 25: ${ }^{1} \mathrm{H}$ NMR (400 $\mathrm{MHz}, \mathrm{CDCl}_{3}$ ) $\delta 11.12$ (s, 2H), 7.21 (t, $J=7.6 \mathrm{~Hz}, 2 \mathrm{H}), 6.77$ (d, $J=7.6 \mathrm{~Hz}, 2 \mathrm{H}), 6.63(\mathrm{~d}, J=7.2 \mathrm{~Hz}, 2 \mathrm{H})$, 5.38-5.41 (m, 2H), 4.55 (q, $J=22.0,6.8 \mathrm{~Hz}, 4 \mathrm{H}), 3.69$ (bs, 2H), 3.37 (q, $J=27.6,9.6 \mathrm{~Hz}$, 4H), 3.25-3.35 (m, 2H), 3.06-5.16 (m, 8H), 3.03 (s, 6H), 2.50 -2.55 (m, 2H), 1.73-1.92 (m, 10H), 1.41-1.59 (m, 36H), 1.06-1.18 (m, 4H), 0.99-1.03 (m, 42H), 0.96 (d, $J=6.8 \mathrm{~Hz}, 6 \mathrm{H})$, 0.77 (s, 6H), 0.70 (s, 6H); ${ }^{13} \mathrm{C}$ NMR (150 MHz, $\left.\mathrm{CDCl}_{3}\right) \delta 171.12,162.22,145.45,134.08$, 133.63, 122.53, 115.62, 112.60, 96.22, 81.87, 77.88, 74.38, 72.43, 69.79, 55.82, 42.00, 39.41, 36.98, 36.82, 36.52, 33.74, 32.03, 31.94, 31.58, 31.24, 28.87, 28.12, 25.06, 24.05, 23.69, 21.57, 20.27, 18.07, 15.62, 11.97; IR (film) 2938, 2865, 1658, 1606, 1449, 1311, 1251, 1212, 1096, 1041, 882, $815 \mathrm{~cm}^{-1} ; \quad[\alpha]_{\mathrm{D}}^{28}=+7.97\left(c=0.37, \mathrm{CH}_{2} \mathrm{Cl}_{2}\right) ; \quad \mathrm{MS}$ (electrospray ionization) calculated for $\mathrm{C}_{86} \mathrm{H}_{148} \mathrm{O}_{16} \mathrm{Si}_{2} \mathrm{Na}[\mathrm{M}+\mathrm{Na}+1]^{+}$: 1516.02 , found 1516.20. 


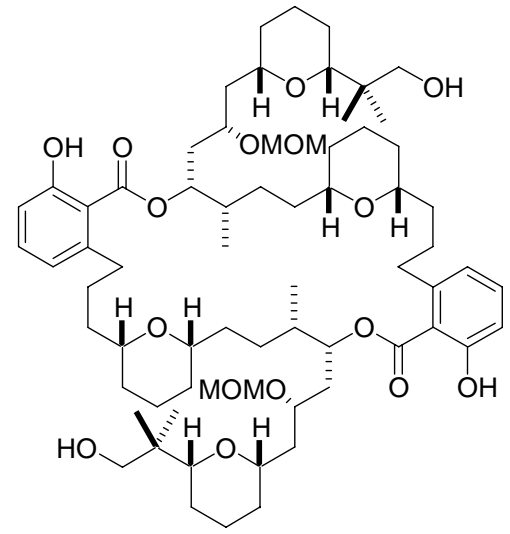

A $20 \mathrm{~mL}$ vial was charged with macrodiolide $25(9.7 \mathrm{mg}, 0.0065 \mathrm{mmol})$ and 2.0 $\mathrm{mL}$ of THF. Tetrabutylammonium fluoride (1.0 M in THF, $0.065 \mathrm{~mL}, 0.065 \mathrm{mmol}$ ) was added and the reaction mixture was stirred overnight. The reaction was quenched with saturated $\mathrm{NH}_{4} \mathrm{Cl}$ and the product was extracted three times with dichloromethane. The combined organic layers were dried over $\mathrm{Na}_{2} \mathrm{SO}_{4}$ and concentrated in vacuo. Purification by flash column chromatography (50\% EtOAc/Hexanes) provided $3.5 \mathrm{mg}$ (46\%) of the diol: ${ }^{1} \mathrm{H}$ NMR (500 MHz, CDCl $) \delta 11.00$ (s, 2H), $7.22(\mathrm{t}, J=7.5 \mathrm{~Hz}, 2 \mathrm{H}), 6.79(\mathrm{~d}, J=8.0 \mathrm{~Hz}$, 2H), 6.65 (d, $J=7.5 \mathrm{~Hz}, 2 \mathrm{H}), 5.38$ (q, $J=11.5,5.5 \mathrm{~Hz}, 2 \mathrm{H}), 4.57$ (q, $J=9.5,6.5 \mathrm{~Hz}, 4 \mathrm{H}$ ), 3.66 (bs, 2H), 3.44 (d, $J=11.0 \mathrm{~Hz}, 2 \mathrm{H}$ ), 3.20-3.37 (m, 2H), 3.31 (s, 6H), 3.21 (d, $J=11.0$ Hz, 2H), 3.08-3.18 (m, 6H), 2.54-2.60 (m, 2H), 1.74-1.84 (m, 10H), 1.36-1.70 (m, 36H), 1.22-1.33 (m, 4H), 1.03-1.18 (m, 4H), 0.97 (d, $J=6.5 \mathrm{~Hz}, 6 \mathrm{H}), 0.79$ (s, 6H), 0.75 (s, 6H); ${ }^{13} \mathrm{C}$ NMR $\left(125 \mathrm{MHz}, \mathrm{CDCl}_{3}\right) \delta 171.02,161.97,145.19,133.58,122.42,115.68,113.00$, 96.66, 85.84, 77.87, 77.36, 75.27, 72.72, 71.05, 55.83, 42.30, 38.07, 37.05, 36.82, 36.39, 33.78, 31.96, 31.84, 31.33, 28.67, 28.15, 25.21, 23.67, 22.68, 20.11, 15.65; IR (film) 3434, 2930, 2359, 1722, 1653, 1605, 1449, 1371, 1310, 1252, 1213, 1092, 1039, 920, $816 \mathrm{~cm}^{-1}$; $[\alpha]_{D}^{26}=+35.6\left(c=0.08, \mathrm{CH}_{2} \mathrm{Cl}_{2}\right) ;$ MS (electrospray ionization) calculated for $\mathrm{C}_{68} \mathrm{H}_{109} \mathrm{O}_{16}$ $[\mathrm{M}+\mathrm{H}]^{+}:$1181.77, found 1181.80 . 


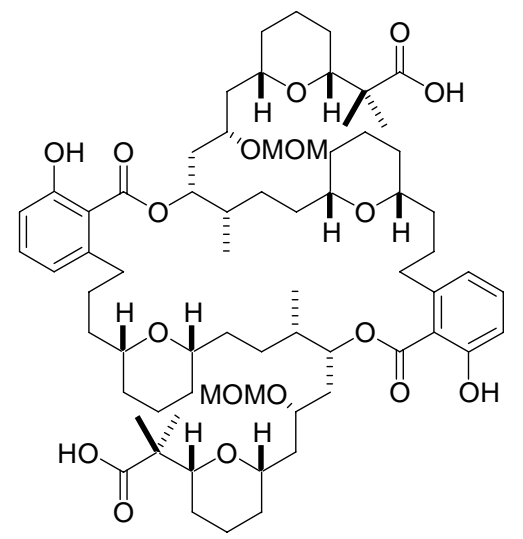

To a $2 \mathrm{~mL}$ vial was added the diol $(2.7 \mathrm{mg}, 0.0023 \mathrm{mmol})$ and $0.750 \mathrm{~mL}$ of dichloromethane. Tetrapropylammonium peruthenate (1 mg, $0.003 \mathrm{mmol})$ and 4methylmorpholine $N$-oxide (1 mg, $0.009 \mathrm{mmol}$ ) were added and the reaction mixture was stirred 30 minutes. The reaction mixture was filtered through a small plug of silica gel eluting with 50\% EtOAc/Hexanes and concentrated in vacuo to provide $1.4 \mathrm{mg}$ (52\%) of the bis-aldehyde. The bis-aldehyde was used immediately in the following oxidation reaction: ${ }^{1} \mathrm{H}$ NMR (500 MHz, $\mathrm{CDCl}_{3}$ ) $\delta 11.16$ (s, 2H), 9.45 (s, 2H), 7.22 (t, $\left.J=8.0 \mathrm{~Hz}, 2 \mathrm{H}\right), 6.79$ (d, $J$ $=8.5,2 \mathrm{H}), 6.64(\mathrm{~d}, J=7.0 \mathrm{~Hz}, 2 \mathrm{H}), 5.37(\mathrm{q}, J=12.5,6.0 \mathrm{~Hz}, 2 \mathrm{H}), 4.54(\mathrm{q}, J=25.0,6.5 \mathrm{~Hz}$, 4H), 3.64 (bs, 2H), 3.27-3.37 (m, 4H), 3.30 (s, 6H), 3.11-3.17 (m, 6H), 2.53-2.56 (m, 2H), 1.74-1.83 (m, 10H), 1.38-1.61 (m, 36H), 1.06-1.22 (m, 4H), 0.98 (d, $J=7.0 \mathrm{~Hz}, 6 \mathrm{H}), 0.92$ (s, 6H), 0.90 (s, 6H).

A $3 \mathrm{~mL}$ vial was charged with the bis-aldehyde (1.4 mg, $0.0019 \mathrm{mmol})$, 2-methyl-2butene $(0.050 \mathrm{~mL}, 0.47 \mathrm{mmol}), 0.500 \mathrm{~mL}$ of tert-butanol, and $0.500 \mathrm{~mL}$ of water. Sodium chlorite (1 mg, $0.0110 \mathrm{mmol})$ and sodium phosphate monobasic, monohydrate (1.6 mg, $0.0116 \mathrm{mmol}$ ) were added and the reaction mixture was stirred 1 hour. The reaction was quenched with water and the mixture was diluted with ethyl acetate. The product was extracted three times with ethyl acetate and the combined organic layers were dried over 
$\mathrm{Na}_{2} \mathrm{SO}_{4}$. Concentration in vacuo followed by purification by flash column chromatography (5\% $\mathrm{MeOH} / \mathrm{CH}_{2} \mathrm{Cl}_{2}$ ) provided $1.4 \mathrm{mg}(97 \%)$ of diacid: ${ }^{1} \mathrm{H}$ NMR $\left(500 \mathrm{MHz}, \mathrm{CDCl}_{3}\right) \delta 7.24$ (t, $J=8.0 \mathrm{~Hz}, 2 \mathrm{H}), 6.80$ (d, $J=7.5 \mathrm{~Hz}, 2 \mathrm{H}), 6.66(\mathrm{~d}, J=7.5 \mathrm{~Hz}, 2 \mathrm{H}), 5.31-5.33(\mathrm{~m}, 2 \mathrm{H})$, 4.58 (q, $J=17.0,7.0 \mathrm{~Hz}, 4 \mathrm{H}), 3.63-3.70$ (m, 2H), 3.44-3.50 (m, 2H), 3.31 (s, 6H), 3.14-3.16 (m, 4H), 3.00-3.05 (m, 2H), 2.56-2.61 (m, 2H), 1.97-2.00 (m, 2H), 1.36-1.92 (m, 30H), 1.11-1.31 (m, 20H), 1.09 (s, 3H), 1.08 (s, 3H), 0.98 (d, $J=7.0 \mathrm{~Hz}, 6 \mathrm{H})$; IR (film) 2928, 1658, 1450, 1090, $1039 \mathrm{~cm}^{-1} ;[\alpha]_{\mathrm{D}}^{25}=+60.0\left(c=0.05, \mathrm{CH}_{2} \mathrm{Cl}_{2}\right) ; \quad$ MS (electrospray ionization) calculated for $\mathrm{C}_{68} \mathrm{H}_{104} \mathrm{O}_{18} \mathrm{Na}[\mathrm{M}+\mathrm{Na}]^{+}:$1231.71, found 1231.80 .

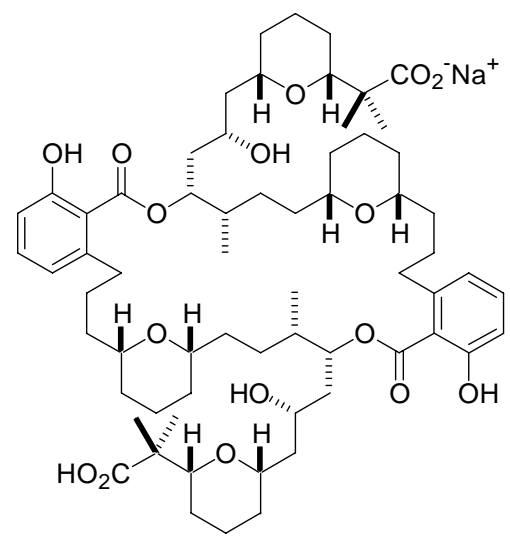

SCH 351448 (1). A polyethylene vial was charged with diacid (1.5 mg, $0.0012 \mathrm{mmol})$ and $1 \mathrm{~mL}$ of acetonitrile. Aqueous $\mathrm{HF}$ ( $48 \%$ in water, $0.020 \mathrm{~mL}, 0.055 \mathrm{mmol}$ ) was added dropwise and the reaction was stirred for 48 hours. The reaction was then diluted with hexanes and washed with $4 \mathrm{~N} \mathrm{HCl}$ (saturated with $\mathrm{NaCl}$ ). The aqueous layer was extracted three times with hexanes and the combined organic layers were dried over $\mathrm{Na}_{2} \mathrm{SO}_{4}$. Concentration in vacuo provided $1.0 \mathrm{mg}(70 \%)$ of $\mathbf{1}:{ }^{1} \mathrm{H}$ NMR $\left(500 \mathrm{MHz}, \mathrm{CDCl}_{3}\right) \delta 7.24(\mathrm{t}$, $J=8.0 \mathrm{~Hz}, 2 \mathrm{H}$ ), 6.80 (d, $J=7.5 \mathrm{~Hz}, 2 \mathrm{H}), 6.71$ (d, $J=7.0 \mathrm{~Hz}, 2 \mathrm{H}), 5.61-5.66$ (m, 2H), 3.703.77 (m, 2H), 3.55-3.64 (m, 2H), 3.51 (d, $J=11.0 \mathrm{~Hz}, 2 \mathrm{H}), 3.07-3.18$ (m, 6H), 2.50-2.56 (m, 2H), 2.00-2.04 (m, 2H), 1.81-1.89 (m, 4H), 1.73-1.78 (m, 2H), 1.64-1.72 (m, 6H), 1.55-1.62 (m, 4H), 1.38-1.54 (m, 22H), 1.18-1.34 (m, 10H), 1.12 (s, 6H), 1.10 (s, 6H), 1.01 (d, $J=6.0$ 
$\mathrm{Hz}, 6 \mathrm{H})$; IR (film) 3428, 2924, 2854, 1705, 1463, $1086 \mathrm{~cm}^{-1} ;[\alpha]^{27}{ }_{\mathrm{D}}=+79.9(\mathrm{c}=0.05$, $\mathrm{CH}_{2} \mathrm{Cl}_{2}$ ); $\mathrm{MS}$ (electrospray ionization) calculated for $\mathrm{C}_{64} \mathrm{H}_{96} \mathrm{NaO}_{18}[\mathrm{M}+\mathrm{H}]^{+}:$1143.66, found 1143.80 . 
- S48 - 